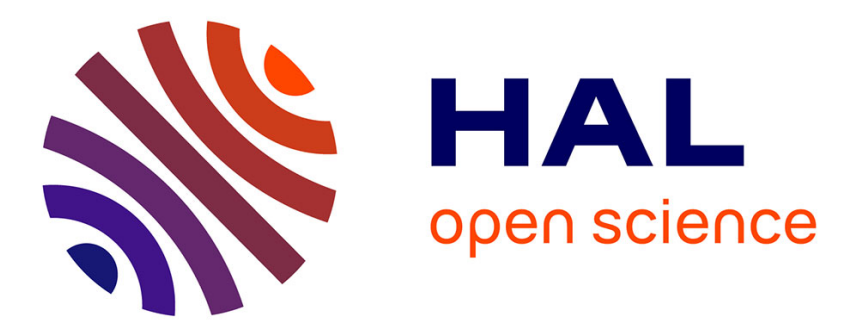

\title{
Characterization of [H]LUF5834: a novel non-ribose high-affinity agonist radioligand for the adenosine A receptor
}

J. Robert Lane, Elisabeth Klaasse, Judy Lin, John van Bruchem, Margot W. Beukers, Adriaan P. Ijzerman

\section{To cite this version:}

J. Robert Lane, Elisabeth Klaasse, Judy Lin, John van Bruchem, Margot W. Beukers, et al.. Characterization of [H]LUF5834: a novel non-ribose high-affinity agonist radioligand for the adenosine A receptor. Biochemical Pharmacology, 2010, 80 (8), pp.1180. 10.1016/j.bcp.2010.06.041 . hal00618176

\section{HAL Id: hal-00618176 https://hal.science/hal-00618176}

Submitted on 1 Sep 2011

HAL is a multi-disciplinary open access archive for the deposit and dissemination of scientific research documents, whether they are published or not. The documents may come from teaching and research institutions in France or abroad, or from public or private research centers.
L'archive ouverte pluridisciplinaire HAL, est destinée au dépôt et à la diffusion de documents scientifiques de niveau recherche, publiés ou non, émanant des établissements d'enseignement et de recherche français ou étrangers, des laboratoires publics ou privés. 


\section{Accepted Manuscript}

Title: Characterization of $\left[{ }^{3} \mathrm{H}\right]$ LUF5834: a novel non-ribose high-affinity agonist radioligand for the adenosine $\mathrm{A}_{1}$ receptor

Authors: J. Robert Lane, Elisabeth Klaasse, Judy Lin, John van Bruchem, Margot W. Beukers, Adriaan P. IJzerman

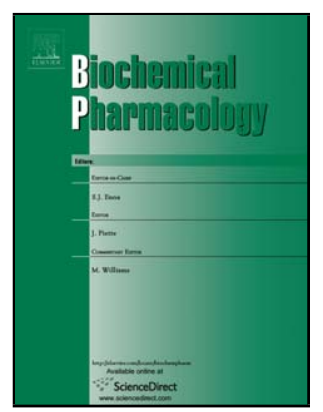

PII:

S0006-2952(10)00475-2

DOI:

doi:10.1016/j.bcp.2010.06.041

Reference:

BCP 10622

To appear in: $\quad B C P$

Received date: $\quad 20-5-2010$

Revised date: 22-6-2010

Accepted date: $\quad$ 22-6-2010

Please cite this article as: Lane JR, Klaasse E, Lin J, van Bruchem J, Beukers MW, IJzerman AP, Characterization of $\left[{ }^{3} \mathrm{H}\right]$ LUF5834: a novel non-ribose high-affinity agonist radioligand for the adenosine $\mathrm{A}_{1}$ receptor, Biochemical Pharmacology (2010), doi:10.1016/j.bcp.2010.06.041

This is a PDF file of an unedited manuscript that has been accepted for publication. As a service to our customers we are providing this early version of the manuscript. The manuscript will undergo copyediting, typesetting, and review of the resulting proof before it is published in its final form. Please note that during the production process errors may be discovered which could affect the content, and all legal disclaimers that apply to the journal pertain. 
Characterization of $\left[{ }^{3} \mathrm{H}\right]$ LUF5834: a novel non-ribose high-affinity agonist radioligand for the adenosine $A_{1}$ receptor

\author{
J. Robert Lane, Elisabeth Klaasse, Judy Lin, John van Bruchem, Margot W. \\ Beukers, Adriaan P. IJzerman \\ Division of Medicinal Chemistry, Leiden/Amsterdam Centre for Drug Research, Leiden \\ University, PO Box 9502, 2300 RA Leiden, The Netherlands
}

J. Robert Lane

Division of Medicinal Chemistry, Leiden/Amsterdam Center for Drug Research, Leiden University, P.O.Box 9502, 2300 RA Leiden, The Netherlands

Phone: +31 - (0)71 527 4268, Fax: + 31 - (0)71 5274565

jrlane@chem.leidenuniv.nl

Number of tables: 5

Number of figures: 7

Number of references: 29

Number of words in abstract: 219

Number of words in introduction: 533

Number of words in discussion: 1522

Key words: adenosine receptor, G protein-coupled receptor, radioligand, partial agonist, inverse agonist 


\begin{abstract}
Abbreviations
Adenosine deaminase, ADA; 3-[(3-cholamidopropyl)dimethylammonio]-1-

propanesulfonate, CHAPS; Chinese hamster ovary, $\mathrm{CHO} ; \mathrm{N}^{6}$-cyclopentyladenosine, CPA; 1,3-dipropyl-8-cyclopentylxanthine, DPCPX; C8-butylamino- $\mathrm{N}^{6}$ cyclopentyladenosine, 8BCPA; C8-ethylamino- $\mathrm{N}^{6}$-cyclopentyladenosine, 8ECPA; 2chloro-N6-cyclopentyladenosine, CCPA; G protein-coupled receptor, GPCR; Guanosine triphosphate, GTP; 2-amino-4-(4-hydroxyphenyl)-6-(1H-imidazol-2-ylmethylsulfanyl)pyridine-3,5-dicarbonitrile, LUF5834.
\end{abstract}




\section{Introduction}

Adenosine is a ubiquitous local hormone that has been reported to play an important role in numerous tissues by acting mainly through four subtypes of adenosine receptors [1]. These receptors $\left(A_{1} R, A_{2 A} R, A_{2 B} R\right.$ and $\left.A_{3} R\right)$ belong to the $G$ protein-coupled receptor (GPCR) superfamily. This study focuses on the human adenosine $A_{1}$ receptor $\left(h A_{1} R\right)$ which primarily couples to $\mathrm{G}_{\mathrm{i} / \mathrm{o}} \mathrm{G}$ proteins which mediate the inhibition of adenylate cyclase. The $A_{1} R$ receptor is widely expressed, being present in the CNS and in peripheral systems such as cardiovascular tissue [1,2]. The wide and abundant distribution of these receptors underlines their important role in the body and therefore they represent targets for useful therapeutic agents $[3,4]$. For example the abundance of the $A_{1} R$ in the atrioventricular node of the heart is the basis for clinical development of selective $A_{1} R$ agonists as antiarrythmic agents [5]. Similarly, activation of $A_{1} R s$ in the spinal cord may represent a novel treatment for neuropathic pain [6].

Historically, agonists for the adenosine receptors have all been derivatives of the endogenous ligand adenosine. For example chemical modification of the adenosine structure particularly at the $\mathrm{N}^{6}, \mathrm{C} 2$ and $\mathrm{C} 5{ }^{\prime}$ positions have yielded selective high affinity agonists[7]. One such example is $\mathrm{N}^{6}$-cyclopentyladenosine (CPA), a high-affinity and selective agonist for the $A_{1} R$. Furthermore the ribose moiety was thought to be essential for the agonistic efficacy of adenosine receptor ligands [8]. However, recent research has challenged this dogma. Rosentreter et al. patented a new class of adenosine receptor ligands, the 2-amino-4-(3,4 substituted phenyl)-6-(2-hydroxyethylsulfanyl)-pyridine-3,5dicarbonitriles $[9,10]$. These compounds were demonstrated to have both a significant 
affinity and efficacy towards different adenosine receptor subtypes [9-12]. One of these compounds, LUF 5831, was shown to be a partial agonist with a high affinity of $18 \mathrm{nM}$ for the $\mathrm{hA}_{1} \mathrm{R}$ [13]. Accordingly, this compound displayed binding characteristics typical of a partial agonist such as an insensitivity to GTP in radioligand binding studies and the ability to bind to a $\mathrm{G}$ protein-uncoupled mutant of the $\mathrm{hA}_{1}$ receptor $\left(\mathrm{hA}_{1}-\mathrm{T}^{277} \mathrm{~A}\right)$. Another high-affinity non-adenosine compound, LUF 5834, was characterized as an agonist at the $\mathrm{hA}_{1} \mathrm{R}$ in a cAMP assay [11]. Furthermore LUF5834 showed a moderate (10 fold) selectivity for the $h \mathrm{~A}_{1} \mathrm{R}$ over the $\mathrm{hA_{2 }}{ }_{\mathrm{A}} \mathrm{R}$ and $\mathrm{hA_{2B }} \mathrm{R}$ and a higher selectivity (100 fold) over the $\mathrm{hA}_{3} \mathrm{R}$ [11]. Consequently it was of interest to further characterize this ligand at the $\mathrm{hA}_{1} \mathrm{R}$. In this paper we confirm that LUF5834 indeed has a high (nanomolar) affinity for the $h A_{1} R$. Using $\left[{ }^{35} \mathrm{~S}\right] \mathrm{GTP} \gamma \mathrm{S}$ binding experiments to measure $\mathrm{hA} \mathrm{A}_{1} \mathrm{R}$ mediated $\mathrm{G}$ protein activation we demonstrate that that LUF5834 is a partial agonist as compared to the reference full agonist CPA. Given the high affinity of LUF5834 it was interesting to radioactively label this agonist with tritium. We demonstrate that $\left[{ }^{3} \mathrm{H}\right]$ LUF5834 is a high affinity radioligand for the $h A_{1} R$ specifically labeling the $h A_{1} R$ expressed in $\mathrm{CHO}$ cells with negligible non-specific binding. Furthermore, due to its high affinity and partial agonist nature $\left[{ }^{3} \mathrm{H}\right]$ LUF5834 was capable of labeling $\mathrm{hA}_{1} \mathrm{R}$ both coupled and uncoupled to $\mathrm{G}$ proteins. This allowed the characterization of high and low affinity binding for both agonists and antagonists at the $\mathrm{hA}_{1} \mathrm{R}$. In summary then we describe a useful and novel high affinity radioligand for the $\mathrm{hA}_{1} \mathrm{R}$. 


\section{Methods}

\subsection{Materials}

$N^{6}$-cyclopentyladenosine (CPA) was obtained from Research Biochemicals Inc. (Natick, MA, U.S.A.). 1,3-dipropyl-8-cyclopentylxanthine (DPCPX), bovine serum albumin (BSA) and 3-[(3-cholamidopropyl)dimethylammonio]-1-propanesulfonate (CHAPS) were from Sigma (St. Louis MO, U.S.A.). Adenosine deaminase (ADA) was purchased from Roche Biochemicals (Mannheim, Germany) and bicinchoninic acid (BCA) protein assay reagent was obtained from Pierce Chemical Company (Rockford, IL, U.S.A.). $\left[{ }^{3} \mathrm{H}\right]$ 1,3-dipropyl-8-cyclopentylxanthine $\left(\left[{ }^{3} \mathrm{H}\right] \mathrm{DPCPX}\right.$-specific activity $\left.124 \mathrm{Ci} / \mathrm{mmol}\right)$ and $\left[{ }^{3} \mathrm{H}\right] \mathrm{CCPA}$ (2-chloro-N6-cyclopentyladenosine, $55 \mathrm{Ci} / \mathrm{mmol}$ ) was purchased from NEN (Du Pont Nemours, 's Hertogenbosch, The Netherlands). [ $\left.{ }^{3} \mathrm{H}\right]$ 2-amino-4-(4hydroxyphenyl)-6-(1H-imidazol-2ylmethylsulfanyl)-pyridine-3,5-dicarbonitrile $\left(\left[{ }^{3} \mathrm{H}\right]\right.$ LUF5834 - specific activity $\left.25 \mathrm{Ci} / \mathrm{mmol}\right)$ was labeled by Sibtech, Inc. (Newington, CT, U.S.A.). Unlabelled LUF5834 was provided as the precursor (synthesized in-house at University of Leiden, Netherlands). Radiolabeling was performed using a halogenation - dehalogenation approach yielding the desired labeled product. The radiolabeled ligand was purified over a Kromasil C18 column with a gradient of $10 \%$ to $50 \% \mathrm{MeCN} / \mathrm{H}_{2} \mathrm{O} / 0.1 \%$ TFA. TLC on $\mathrm{SiO}_{2}$ was developed with $\mathrm{CH}_{2} \mathrm{Cl}_{2}: \mathrm{MeOH}: \mathrm{NH}_{4} \mathrm{OH}$ (10:1.5:0.25). TLC on C18 was developed with $\mathrm{MeOH}: 0.1 \mathrm{M} \mathrm{NH}_{4} \mathrm{OAc}$ pH 3.5 (3:1). Radiochemical purity was 98\% . G418 (neomycin) was obtained from Stratagene (Cedar Creek, U.S.A.). Guanosine triphosphate (GTP) was purchased from Acros Organics (Geel, Belgium). LUF5834 was synthesized in our laboratory as described by Chang et al. (2005) [12]. C8-butylamino- $\mathrm{N}^{6}$ cyclopentyladenosine (8BCPA) and C8-ethylamino- 
$\mathrm{N}^{6}$-cyclopentyladenosine (8ECPA) were synthesised as previously described [14]. Chinese hamster ovary $(\mathrm{CHO})$ cells stably expressing the $h \mathrm{~A}_{1} \mathrm{R}$ or the $\mathrm{hA}_{2 \mathrm{~B}} \mathrm{R}$ were obtained from Prof. Steve Hill (University of Nottingham, UK) or S.Rees (GSK, Stevenage, UK). HEK293 cells stably expressing the $\mathrm{hA}_{2 \mathrm{~A}} \mathrm{R}$ were kindly provided by Dr. J Wang (Biogen/IDEC, Cambridge, MA) All other chemicals were of analytical grade and obtained from standard commercial sources.

\subsection{Cell culture}

Chinese hamster ovary $(\mathrm{CHO})$ cells stably expressing the human adenosine $\mathrm{A}_{1}$ receptor $\left(\mathrm{CHO}-\mathrm{hA} \mathrm{A}_{1}\right)$ or the human $\mathrm{A}_{2 \mathrm{~B}}$ receptor $\left(\mathrm{CHO}-\mathrm{hA} \mathrm{A}_{2 \mathrm{~B}}\right)$ were cultured in a 1:1 mixture of Dulbecco's modified Eagle's medium (DMEM) and Ham's F12 medium containing 10\% newborn calf serum, $50 \mu \mathrm{g} / \mathrm{mL}$ streptomycin, $50 \mathrm{IU} / \mathrm{mL}$ penicillin and $0.2 \mathrm{mg} / \mathrm{mL}$ neomycin (G418). Human embryonic kidney cells (HEK293) stably expressing the hA ${ }_{2 \mathrm{~A}} \mathrm{R}$ were cultured in Dulbecco's modified Eagle's medium (DMEM) containing 10\% newborn calf serum, $50 \mu \mathrm{g} / \mathrm{mL}$ streptomycin, $50 \mathrm{IU} / \mathrm{mL}$ penicillin and $0.2 \mathrm{mg} / \mathrm{mL}$ neomycin (G418). The cells were maintained in a humidified atmosphere at $37^{\circ} \mathrm{C}$ and $5 \% \mathrm{CO}_{2}$

\subsection{Membrane preparation}

Membranes of $\mathrm{CHO}$ or HEK293 cells stably expressing the $\mathrm{hA}_{1} \mathrm{R}, \mathrm{hA}_{2 \mathrm{~A}}$ or $\mathrm{hA}_{2 \mathrm{~B}}$ were prepared as previously described [13]. Membrane protein concentrations were measured using the BCA (bicinchoninic acid) method with BSA as a standard. 


\subsection{Radioligand-binding assays}

For experiments using $\left[{ }^{3} \mathrm{H}\right]$ LUF5834, membrane aliquots containing $10 \mu \mathrm{g}\left(\mathrm{CHO}-\mathrm{hA} \mathrm{A}_{1}\right)$ protein were incubated in a total volume of $400 \mu \mathrm{l}$ of $50 \mathrm{mM}$ Tris- $\mathrm{HCl}, 0.1 \%$ CHAPS, ADA (1U/mL) $\mathrm{pH} 7.4$, at $25^{\circ} \mathrm{C}$ for $60 \mathrm{~min}$ in the absence or presence of $1 \mathrm{mM} \mathrm{GTP}$. Displacement experiments were performed using 24 concentrations of unlabeled ligand in the presence of $2.6 \mathrm{nM}\left[{ }^{3} \mathrm{H}\right]$ LUF5834. Nonspecific binding was determined in the presence of $10 \mu \mathrm{M} \mathrm{CPA}$ and represented approximately $10 \%$ of the total binding. Saturation experiments were carried out using nine to 21 different concentrations of $\left[{ }^{3} \mathrm{H}\right]$ LUF5834. In kinetic studies, the association of the radioligand $\left[{ }^{3} \mathrm{H}\right] \mathrm{LUF5834}$ (2.6 $\mathrm{nM})$ was initiated by addition of the membrane preparation $(10 \mu \mathrm{g})$ to the radioligand. To study the dissociation of $\left[{ }^{3} \mathrm{H}\right]$ LUF5834, membranes were preincubated with $\left[{ }^{3} \mathrm{H}\right]$ LUF5834 $(2.6 \mathrm{nM})$ at $25{ }^{\circ} \mathrm{C}$ for $60 \mathrm{~min}$. Dissociation of $\left[{ }^{3} \mathrm{H}\right]$ LUF5834 was then initiated by the addition of LUF5834 $(1 \mu \mathrm{M})$ or CPA $(10 \mu \mathrm{M})$. Incubations were terminated by dilution with ice-cold $50 \mathrm{mM}$ Tris- $\mathrm{HCl}$ buffer. Separation of bound from free radioligand was performed by rapid filtration through Whatman GF/C filters using a Brandel harvester. Filters where subsequently washed three times with ice-cold buffer, or six times in saturation experiments. Filter-bound radioactivity was measured by scintillation spectrometry (Tri-Carb 2900TR, Perkin Elmer) after addition of $3.5 \mathrm{~mL}$ Packard Emulsifier Safe. Experiments were performed at least three times in duplicate, unless otherwise stated. Experiments using $\left[{ }^{3} \mathrm{H}\right] \mathrm{DPCPX}$ were performed as above with non-specific binding determined using $100 \mu \mathrm{M}$ CPA. Experiments using $\left[{ }^{3} \mathrm{H}\right] \mathrm{CCPA}$ 
were performed as above using $30 \mu \mathrm{g}$ of receptor per assay point and non-specific binding was determined using $10 \mu \mathrm{M}$ DPCPX.

We performed similar studies on membranes expressing the $\mathrm{hA}_{2 \mathrm{~A}} \mathrm{R}$ or $\mathrm{hA} \mathrm{B}_{\mathrm{B}} \mathrm{R}$ to assess the radioligand's potential to label these adenosine receptor subtypes as well.

\section{$2.5 h A_{1} R$-mediated $\left[{ }^{35} S\right] G T P \gamma S$ binding.}

Membrane homogenates $\left(\mathrm{CHO}-\mathrm{hA}_{1}, 5 \mu \mathrm{g}\right)$ were equilibrated in a $90 \mu \mathrm{L}$ total volume of assay buffer (50 mM Tris, $200 \mathrm{mM} \mathrm{NaCl}, 10 \mathrm{mM} \mathrm{MgCl}_{2}$, $\mathrm{pH}$ 7.4) containing $3 \mu \mathrm{M}$ GDP and a range of concentrations of ligand at $25^{\circ} \mathrm{C}$ for 30 minutes. After this $10 \mu \mathrm{L}$ of $\left[{ }^{35} \mathrm{~S}\right] \mathrm{GTP} \gamma \mathrm{S}$ (final concentration $0.3 \mathrm{nM}$ ) was added and incubation continued for 45 minutes at $25^{\circ} \mathrm{C}$. Incubation was terminated by rapid filtration through a 96 well Unifilter (PerkinElmer, NL) using a Filtermate Unifilter 96-well harvester (Perkin Elmer). Filters were washed three times with ice-cold assay buffer before drying. $25 \mu \mathrm{L}$ of Microscint scintillation cocktail was added to each well, and plates were counted in a 1450 Trilux Microbeta liquid scintillation and luminescence counter (Perkin Elmer).

\subsection{Data analysis}

Data of radioligand binding experiments were analyzed using the non-linear regression curve fitting program Prism 5 (GraphPad, San Diego, CA, USA). Kinetic $k_{\text {on }}$ and $k_{\text {off }}$ values were obtained by computer analysis of the association and dissociation data. Both association and dissociation experiments showed a two site binding profile for $\left[{ }^{3}\right.$ H]LUF5834. Saturation curves were fitted using either a one site isotherm or a one site isotherm with a variable Hill slope. For $\left[{ }^{3} \mathrm{H}\right] \mathrm{DPCPX}$ a one site binding curve was 
favored. For $\left[{ }^{3}\right.$ H]LUF5834 saturation however a one site isotherm with a variable Hill slope was favored and in three out of the seven experiments a two site binding equation could be fitted. Radioligand displacement curves were fitted to one and two state/site binding models. For the displacement of $\left[{ }^{3} \mathrm{H}\right]$ DPCPX by LUF5834 a one site model with a variable Hill slope was preferred using the equation;

$$
Y=\frac{(\text { top }- \text { bottom }) x^{n_{H}}}{x^{n H}+I C_{50}^{n_{H}}}
$$

where $\mathrm{Y}$ denotes the percent specific binding, top and bottom denote the maximal and minimal asymptotes respectively, $\mathrm{x}$ denotes the inhibitor potency (midpoint location) parameter and $\mathrm{n}_{\mathrm{H}}$ denotes the Hill slope factor. Assuming simple competition $\mathrm{IC}_{50}$ values were converted to $\mathrm{K}_{\mathrm{i}}$ values using the Cheng and Prusoff (1973) equation.

The CPA, DPCPX and N0840 displacement curves were best fitted to a two state/site binding model. For 8BCPA and 8ECPA one site binding isotherms were preferred. For experiments using $\left[{ }^{3} \mathrm{H}\right] \mathrm{LUF5834} \mathrm{IC}_{50}$-values were taken instead of calculated $\mathrm{K}_{\mathrm{i}}$-values, since we did not attempt to attribute $\mathrm{K}_{\mathrm{d}}$-values to each affinity state.

In the functional $\left[{ }^{35} \mathrm{~S}\right] \mathrm{GTP} \gamma \mathrm{S}$ assay, agonist concentration response curves were fitted to the following four-parameter Hill equation using Prism 5;

$$
\text { response }=\frac{(\text { top }- \text { bottom })}{1+\left(10^{\log E C_{50}} / x\right)^{n_{H}}}
$$

where top represents the maximal asymptote of the concentration response curves, bottom represents the lowest asymptote of the concentration-response curves, $\log \mathrm{EC}_{50}$ 
represents the logarithm of the agonist $\mathrm{EC}_{50}$, $\mathrm{x}$ represents the concentration of the agonist and $n_{H}$ represents the Hill slope. Data shown are the mean \pm SEM of at least 3 separate experiments performed in duplicate. Comparisons between models were performed by applying the F-test in Prism 5. Unless otherwise stated values of $p<0.05$ were taken as statistically significant.

\subsection{Results}

\subsection{Characterization of LUF5834, a novel non-ribose agonist at the $h \mathrm{~A}_{1} \mathrm{R}$}

In a preliminary screen LUF5834 was shown to have a high (nanomolar) affinity for the $h A_{1} R$ (Beukers et al, 2004). It was thought worthwhile to characterize this novel agonist more thoroughly. Firstly we tested the ability of 12 increasing concentrations of LUF5834 to displace $\left[{ }^{3} \mathrm{H}\right] \mathrm{DPCPX}$ binding at the $\mathrm{hA_{1 }}$ R expressed in $\mathrm{CHO}$ cell membranes $\left(\mathrm{CHO}-\mathrm{hA}_{1}\right)$. As shown in Figure 1A and Table 1 this displacement was best characterized by a monophasic curve with a variable Hill slope yielding a $\mathrm{K}_{\mathrm{i}}$ value of 3nM and a Hill slope of 0.74 . The affinity of LUF5834 and the Hill slope was unaffected 
by the addition of $1 \mathrm{mM}$ GTP. It should be noted that in three out of six experiments the data could be fit to a biphasic curve with a subnanomolar $\mathrm{K}_{\mathrm{iH}}(0.3 \mathrm{nM})$ and a $\mathrm{K}_{\mathrm{iL}}$ of $6 \mathrm{nM}$. These high and low affinity sites were only moderately affected by the addition of GTP, exhibiting 2 and 5- fold decreases in affinity respectively $\left(\mathrm{K}_{\mathrm{iH}}\right.$ of $0.7 \mathrm{nM}$ and a $\mathrm{K}_{\mathrm{iL}}$ of 18 $\mathrm{nM})$, or when measured on pertussis toxin-treated membranes $\left(\mathrm{K}_{\mathrm{iH}}\right.$ of $0.7 \mathrm{nM}$ and a $\mathrm{K}_{\mathrm{iL}}$ of $34 \mathrm{nM}$ ). This relative insensitivity to GTP and pertussis toxin seems remarkable in terms of the observation that LUF5834 is a full agonist in a cyclic AMP assay. To assure ourselves that this effect was associated with the nature of the ligand rather than the receptor or indeed our experimental method, parallel experiments were performed on the same membranes using the typical agonist CPA as the competing ligand (Figure 1B, Table 1). As might be expected for a full agonist the displacement was best fit using a two site binding isotherm with a high affinity site $\left(\mathrm{K}_{\mathrm{iH}}=7 \mathrm{nM}\right)$ and a low affinity site with a $\mathrm{K}_{\mathrm{iL}}$ of $389 \mathrm{nM}$. However, in the case of CPA the high affinity site was lost when an equivalent experiment was performed in the presence of $1 \mathrm{mM}$ GTP. Furthermore, the high affinity site was not observed when the assay was performed using $\mathrm{CHO}-\mathrm{hA}_{1}$ membranes derived from pertussis toxin-treated cells.

\subsection{Characterization of $\left[{ }^{3} \mathrm{H}\right] \mathrm{LUF5834}$, a high affinity radioligand at the human $\mathrm{A}_{1}$ adenosine receptor}

The above data describing the characterization of LUF5834 underline its behavior as a novel high affinity agonist ligand for the $\mathrm{hA}_{1} \mathrm{R}$ with characteristics different from the 
reference 'ribose' agonist CPA. Therefore LUF5834 could be a potentially useful and novel type of radioligand. Consequently, LUF5834 was radiolabelled giving $\left[{ }^{3} \mathrm{H}\right]$ LUF5834 with a specific activity of $25 \mathrm{Ci} / \mathrm{mmol}$. The conditions employed for the binding of $\left[{ }^{3} \mathrm{H}\right] \mathrm{DPCPX}$ to $\mathrm{CHO}-\mathrm{hA}_{1}$ membranes were used as a basis for an assay for $\left[{ }^{3} \mathrm{H}\right]$ LUF5834. Membrane protein $(10 \mu \mathrm{g})$ was incubated in a total volume of $400 \mu \mathrm{L}$ Tris-HCL buffer, 50 mM, pH 7.4 as described in Methods. On control, untransfected, CHO cell membranes, $\left[{ }^{3} \mathrm{H}\right]$ LUF5834 did not display any specific binding (data not shown). The use of GF/B versus GF/C filters with or without pre-soaking the filters with $0.25 \%$ poly(ethyleneimine) solution (PEI) for 1 hour had no effect on the 'window' of specific binding observed. However, the addition of $0.1 \%$ CHAPS increased the window of specific binding (data not shown). All subsequent assays were therefore performed in the above conditions with the addition of $0.1 \%$ CHAPS and reactions were terminated by fast flow filtration through $\mathrm{GF} / \mathrm{C}$ filters. In identical assay conditions the ability of $\left[{ }^{3} \mathrm{H}\right] \mathrm{LUF5834}$ to bind to the human $\mathrm{A}_{2 \mathrm{~A}}$ receptor expressed in HEK293 cell membranes or to the human $\mathrm{A}_{2 \mathrm{~B}}$ receptor expressed in $\mathrm{CHO}$ cell membranes was assessed using a final concentration of $20 \mathrm{nM}\left[{ }^{3} \mathrm{H}\right]$ LUF5834. No specific binding was detected for the HEK-hA $\mathrm{A}_{2 \mathrm{~A}}$ membranes. For experiments with the $\mathrm{CHO}-\mathrm{hA} 2 \mathrm{~B}$ membranes a small window (200 dpm) of specific binding was detected. However, the relatively high amounts of radioligand and membranes required and the high non-specific binding $(1000 \mathrm{dpm})$ observed in these experiments kept us from further characterization of this probe as a radioligand for $\mathrm{hA}_{2 \mathrm{~B}} \mathrm{Rs}$ (data not shown).

\section{$3.3\left[{ }^{3} \mathrm{H}\right]$ LUF5834 demonstrates biphasic association and dissociation kinetics}




\subsection{Radioligand saturation binding experiments at $\mathrm{h} \mathrm{A}_{1}-\mathrm{CHO}$ membranes using} $\left[{ }^{3}\right.$ H]LUF5834

Saturation experiments were performed with $\left[{ }^{3} \mathrm{H}\right] \mathrm{LUF} 5834$ on $\mathrm{CHO}-\mathrm{hA} \mathrm{A}_{1}$ membranes. The binding of $\left[{ }^{3} \mathrm{H}\right]$ LUF5834 was best characterized using a one-site model but with a variable Hill slope (Figure 3A, Table 3). With this fit a $\mathrm{K}_{\mathrm{d}}$ of $2.03 \pm 0.52 \mathrm{nM}$ and a $\mathrm{B}_{\max }$ of $10.70 \pm 0.76 \mathrm{pmol} / \mathrm{mg}$ was determined. The Hill slope was shown to be $0.78 \pm 0.02$ 
which is significantly lower than unity. This is graphically demonstrated in the Scatchard plot (Figure 3Aii) where a distinct deviation from linearity occurred. A Hill slope of less than unity can be explained by a negatively co-operative binding mechanism or suggests the presence of multiple binding sites. Interestingly the competition of LUF5834 versus DPCPX was also best fit by a curve with a Hill slope of 0.77 . Indeed, in three out of the seven experimental repeats of saturation binding, the curve was well fit by a two site binding isotherm. The two sites were shown to have $\mathrm{K}_{\mathrm{d}}$ values of $0.16 \mathrm{nM}$ and $1.69 \mathrm{nM}$ and gave $\mathrm{B}_{\max }$ values of $1.7 \mathrm{pmol} / \mathrm{mg}$ and $7.9 \mathrm{pmol} / \mathrm{mg}$ respectively (Table 3). These values correspond well to the values of $\mathrm{K}_{\mathrm{iH}}$ and $\mathrm{K}_{\mathrm{iL}}$ determined for LUF5834 in competition binding experiments with $\left[{ }^{3} \mathrm{H}\right] \mathrm{DPCPX}$ (Table 1). This gave a combined $\mathrm{B}_{\max }$ of $9.58 \pm 0.32 \mathrm{pmol} / \mathrm{mg}$ protein, which is not significantly different from that determined using the one-phase curve with variable Hill slope. Parallel experiments using $\left[{ }^{3} \mathrm{H}\right] \mathrm{DPCPX}$ saturation binding on $\mathrm{hA}_{1}-\mathrm{CHO}$ membranes experiments were also performed. In this case the data was best fit using a single site model with a $\mathrm{K}_{\mathrm{d}}$ of $2.87 \pm$ $0.39 \mathrm{nM}$ and $\mathrm{B}_{\max }$ of $12.8 \pm 1.7 \mathrm{pmol} / \mathrm{mg}$ protein (Figure 3B i). The total density of ligand binding sites observed for both $\left[{ }^{3} \mathrm{H}\right] \mathrm{DPCPX}$ and $\left[{ }^{3} \mathrm{H}\right] \mathrm{LUF5834}$ was not significantly different. The monophasic nature of the curve is well demonstrated by the tight linear fit of the Scatchard plot in contrast to that of LUF5834 (Figure 3B ii). This demonstrates that the low Hill slopes and biphasic nature of $\left[{ }^{3} \mathrm{H}\right] \mathrm{LUF5834}$ saturation isotherms are most likely associated with the nature of the ligand, as this was the only variable in the experiments. The biphasic association and dissociation kinetics also suggests the presence of two distinct binding sites labelled by $\left[{ }^{3} \mathrm{H}\right]$ LUF5834 (Table 3). 


\subsection{Displacement of $\left[{ }^{3} \mathrm{H}\right]$ LUF5834 by the agonists LUF 5834 and CPA}

For the experiments describing the displacement of $\left[{ }^{3} \mathrm{H}\right] \mathrm{LUF} 5834$ by various $\mathrm{hA}{ }_{1} \mathrm{R}$ ligands a concentration of $2.6 \mathrm{nM}$ was used. This corresponds to the $\mathrm{K}_{\mathrm{d}}$ value determined by saturation analysis using a variable Hill slope plot. Using this concentration yields a window of specific binding of around $2000 \mathrm{dpm}$, a practical window for this type of experiment. However, we have also given considerable evidence that $\left[{ }^{3} \mathrm{H}\right] \mathrm{LUF5834}$ labels two distinct binding sites with sub-nanomolar and nanomolar affinities. In addition, in displacement experiments of $\left[{ }^{3} \mathrm{H}\right] \mathrm{DPCPX}$ versus LUF5834, $1 \mathrm{mM}$ GTP had negligible effect on either of these two sites suggesting that neither corresponds to a $G$ protein-coupled state. Therefore, values of affinity for each of the displacing ligands are left as values of $\mathrm{pIC}_{50}$, i.e. not converted to apparent $\mathrm{pK}_{\mathrm{i}}$ values. Displacement of $\left[{ }^{3}\right.$ H]LUF5834 by unlabelled LUF5834 was best characterized by a monophasic curve with a high affinity binding site with an $\mathrm{IC}_{50}$ value of $5 \mathrm{nM}$ (Figure 4A, Table 4). As shown in figure $\mathbf{4 A}$, the addition of $1 \mathrm{mM}$ GTP had negligible effect on the observed $\mathrm{IC}_{50}$. However, in the presence of $1 \mathrm{mM}$ GTP a reduction in total counts (Figure 5Aii) was observed. In contrast, the typical $\mathrm{hA}_{1} \mathrm{R}$ agonist CPA displayed a biphasic displacement of $\left[{ }^{3} \mathrm{H}\right]$ LUF5834 with an $\mathrm{IC}_{50 \mathrm{H}}$ of $5 \mathrm{nM}$ and an $\mathrm{IC}_{50 \mathrm{~L}}$ of $340 \mathrm{nM}$ (Figure 4B, Table 4). These values are consistent with the values of $K_{i h}$ and $K_{i l}$ determined by competition of $\left[{ }^{3} \mathrm{H}\right] \mathrm{DPCPX}$. With the addition of $1 \mathrm{mM} \mathrm{GTP}$, the affinity of CPA for the $\mathrm{hA}_{1}$ receptor was not affected but the percentage of high affinity binding sites decreased from $56 \%$ in the absence to $22 \%$ in the presence of GTP (Table 4). However, when 
$\left[{ }^{3} \mathrm{H}\right]$ LUF5834 was used at a concentration of $2.6 \mathrm{nM}$ the addition of $1 \mathrm{mM}$ GTP gave a decrease of approximately $30 \%$ of $\left[{ }^{3} \mathrm{H}\right]$ LUF5834 bound (Figure 4Aii, 4Bii) . This would suggest then a fraction of bound $\left[{ }^{3} \mathrm{H}\right]$ LUF5834 is sensitive to GTP. Therefore it was of interest to investigate the ability of increasing concentrations of GTP to displace $2.6 \mathrm{nM}$ $\left[{ }^{3} \mathrm{H}\right]$ LUF5834 binding at the $\mathrm{hA}_{1} \mathrm{R}$. As a comparison the effect of increasing concentrations of GTP on the binding of $\left[{ }^{3} \mathrm{H}\right] \mathrm{CCPA}$ and $\left[{ }^{3} \mathrm{H}\right] \mathrm{DPCPX}$, a full agonist radioligand and an inverse agonist radioligand respectively, was also tested (Figure 4C). As might be expected, increasing concentrations of GTP had no significant effect on the binding of $\left[{ }^{3} \mathrm{H}\right] \mathrm{DPCPX}$, although a slight increase in ligand binding was observed (Figure 4C). Conversely the binding of $\left[{ }^{3} \mathrm{H}\right] \mathrm{CCPA}$ was almost completely abolished with the addition of $1 \mathrm{mM}$ GTP. Interestingly, increasing concentrations of GTP caused a maximum of $40 \%$ displacement of LUF5834 binding (Figure 4C).

\subsection{Displacement of specific $\left[{ }^{3} \mathrm{H}\right]$ LUF5834 binding by the partial agonists C8- ethylamino- $\mathrm{N}^{6}$-cyclopentyladenosine (8ECPA) or C8-butylamino- $\mathrm{N}^{6}$ - cyclopentyladenosine (8BCPA)}

It was interesting to observe that LUF5834, both in competition with $\left[{ }^{3} \mathrm{H}\right] \mathrm{DPCPX}$ or indeed with $\left[{ }^{3} \mathrm{H}\right]$ LUF5834, displayed no shift in affinity or loss of high affinity binding with the addition of $1 \mathrm{mM} \mathrm{GTP.} \mathrm{We} \mathrm{assessed} \mathrm{the} \mathrm{ability} \mathrm{of} \mathrm{two} \mathrm{reference} \mathrm{partial} \mathrm{agonists}$ C8-butylamino- $\mathrm{N}^{6}$-cyclopentyladenosine (8BCPA) or C8-ethylamino- $\mathrm{N}^{6}$ cyclopentyladenosine (8ECPA) to displace $\left[{ }^{3} \mathrm{H}\right]$ LUF5834 in the presence or absence of 1 mM GTP (Figure 5, Table 4). Unlike the full agonist CPA, the displacement of 
$\left[{ }^{3} \mathrm{H}\right]$ LUF5834 by 8BCPA and 8ECPA was best fit using a monophasic isotherm. The addition of $1 \mathrm{mM}$ GTP produced a negligible reduction in affinity and a modest reduction in affinity for 8BCPA and 8ECPA respectively $\left(\mathrm{pIC}_{50 \mathrm{GTP}}-\mathrm{pIC}_{50 \mathrm{control}}=0.06\right.$ and 0.16$)$. In comparison the addition of $1 \mathrm{mM}$ GTP caused a reduction in the percentage of receptors with a high affinity for the full agonist CPA. If we determine a value of affinity change for CPA in the presence and absence of GTP by subtracting the $\mathrm{pK}_{\mathrm{i}}$ value determined with GTP from the $\mathrm{pK}_{\mathrm{h}}$ value determined without it we observed a much more substantial change of 1.96 .

\subsection{Displacement of $\left[{ }^{3}\right.$ H]LUF5834 by the inverse agonists /antagonists DPCPX and N0840}

Next, it was of interest to investigate the ability of the previously well characterized inverse agonist, DPCPX, to displace $\left[{ }^{3} \mathrm{H}\right] \mathrm{LUF5834}$ at the $\mathrm{hA}_{1} \mathrm{R}$. Interestingly this displacement was best characterized by a biphasic curve with an $\mathrm{IC}_{50 \mathrm{H}}$ of $8.5 \mathrm{nM}$ and an $\mathrm{IC}_{50 \mathrm{~L}}$ of $182 \mathrm{nM}$ (Figure 6A, Table 4). With the addition of $1 \mathrm{mM}$ GTP, the low affinity binding site was lost. Furthermore, when identical experiments were performed on CHO$\mathrm{hA}_{1}$ membranes from cells which had been pre-treated with pertussis toxin DPCPX displaced $\left[{ }^{3} \mathrm{H}\right]$ LUF5834 with a monophasic curve yielding an $\mathrm{IC}_{50}$ value equivalent to the $\mathrm{IC}_{50 \mathrm{~L}}$ observed in the control experiment (Figure 6A, Table 4). We next characterized the ability of the putative neutral antagonist N0840 to displace $\left[{ }^{3} \mathrm{H}\right]$ LUF5834. If N0840 acted as a neutral antagonist we might expect to observe a monophasic displacement 
curve that is not sensitive to the inclusion of $1 \mathrm{mM} \mathrm{GTP.} \mathrm{In} \mathrm{reality,} \mathrm{though,} \mathrm{we} \mathrm{observed}$ a biphasic curve with an $\mathrm{IC}_{50 \mathrm{~L}}$ of $8 \mu \mathrm{M}$ and an $\mathrm{IC}_{50 \mathrm{H}}$ of $455 \mathrm{nM}$ (Figure 6B, Table 4).

With the addition of $1 \mathrm{mM}$ GTP the low affinity site was lost demonstrating that this site is dependent on the coupling of the receptor to $\mathrm{G}$ protein. It is interesting to note the relative change in affinity with and without the presence of GTP as determined by $\mathrm{pIC}_{50 \mathrm{LGTP}}-\mathrm{pIC}_{50 \mathrm{H}}$ was smaller for N0840 than that of DPCPX (-0.92 and -1.33 respectively).

\section{$3.8\left[{ }^{35} \mathrm{~S}\right] \mathrm{GTP} \gamma \mathrm{S}$ binding experiments reveal LUF 5834 to be a partial agonist}

To obtain an accurate measurement of ligand efficacy we investigated the ability of LUF5834 to stimulate $\mathrm{hA}{ }_{1} \mathrm{R}$-mediated guanine nucleotide exchange using a $\left[{ }^{35} \mathrm{~S}\right] \mathrm{GTP} \gamma \mathrm{S}$ binding assay. $\left[{ }^{35} \mathrm{~S}\right] \mathrm{GTP} \gamma \mathrm{S}$ binding experiments were performed on membranes derived from the same $\mathrm{CHO}-\mathrm{hA}_{1} \mathrm{R}$ as used for all radioligand binding studies (figure 7, Table 5). As compared to the reference full agonist CPA which had a potency of $5 \mathrm{nM}$, LUF5834 was a partial agonist with a higher potency $(3 \mathrm{nM})$ and an $\mathrm{E}_{\max }$ of $70 \%$ of the maximal stimulation by CPA. Compared to LUF5834 the previously characterized partial agonists 8BPCA and 8ECPA demonstrated low potency at the $\mathrm{hA}_{1} \mathrm{R}(2 \mu \mathrm{M}$ and $1 \mu \mathrm{M}$, respectively). It is interesting to note that $8 \mathrm{BCPA}$ which showed a similar insensitivity to the addition of GTP in radioligand displacement assays to LUF5834 also demonstrated a similar efficacy in the $\left[{ }^{35} \mathrm{~S}\right] \mathrm{GTP} \gamma \mathrm{S}$ assay. DPCPX was shown to be an efficacious inverse agonist with a potency of $11 \mathrm{nM}$. In comparison N0840 had a much more modest 
potency $(20 \mu \mathrm{M})$ and was an inverse agonist, although with a lower efficacy than DPCPX

\section{Discussion}

The 2-amino-4-(substituted phenyl)-6-(substituted sulfanyl)-pyridin-3,5-dicarbonitriles show no structural similarity to adenosine. However, it has been observed that several compounds of this class display a significant affinity and efficacy towards the different adenosine receptor subtypes. LUF5834 (2-amino-4-(4-hydroxyphenyl)-6-(1H-imidazol2-ylmethylsulfanyl)-pyridine-3,5-dicarbonitrile) has previously been characterized as a novel high affinity non-ribose agonist for the $\mathrm{hA} \mathrm{A}_{1} \mathrm{R}$ (Beukers et al, 2004). We now demonstrate that, in more elaborate studies, the compound displayed two binding sites with a high sub-nanomolar and nanomolar affinity for this receptor, respectively. The high affinity of LUF5834 made it a suitable candidate for labeling with tritium to provide a new radioligand for the $A_{1} R$. Current adenosine $A_{1}$ receptor radioligands are confined to adenosine derivative full agonists such as $\left[{ }^{3} \mathrm{H}\right] \mathrm{CCPA}$ or xanthine derivative inverse agonists such as $\left[{ }^{3} \mathrm{H}\right] \mathrm{DPCPX}[15,16]$. Initial experiments demonstrated that $\left[{ }^{3} \mathrm{H}\right]$ LUF5834 could label $\mathrm{A}_{1}$ Rs with low non-specific binding. Furthermore, using the assay conditions described above, we have demonstrated that $\left[{ }^{3} \mathrm{H}\right]$ LUF5834 selectively labels $\mathrm{A}_{1}$ Rs over $\mathrm{A}_{2 \mathrm{~A}} \mathrm{Rs}$ and $\mathrm{A}_{2 \mathrm{~B}} \mathrm{Rs}$, and that $\left[{ }^{3} \mathrm{H}\right] \mathrm{LUF} 5834$ does not represent a radioligand for the latter receptors. In all saturation experiments the data was well fit using a single site binding model with a variable Hill slope and a $\mathrm{K}_{\mathrm{d}}$ of approx. $2 \mathrm{nM}$ and a $B_{\max }$ of approx, $10 \mathrm{pmol} / \mathrm{mg}$. The Hill slope $(0.78 \pm 0.02)$ was significantly less than unity which is suggestive of either negative co-operative binding or indeed the presence 
of two populations of receptor with distinct affinities for the receptor. Indeed, three out of the seven experiments could be well fit with a two binding site equation with values of $\mathrm{K}_{\mathrm{d}}$ similar to those values of $\mathrm{K}_{\mathrm{i}}$ determined using $\left[{ }^{3} \mathrm{H}\right] \mathrm{DPCPX}$ competition experiments. Kinetic experiments demonstrated that both association and dissociation of $\left[{ }^{3} \mathrm{H}\right] \mathrm{LUF} 5834$ were biphasic. The rate of dissociation observed remained unchanged when either the reference agonist CPA or the cold ligand LUF5834 was used as the displacing ligand. This indicates then that the binding site of LUF5834 overlaps greatly with that of the typical $\mathrm{A}_{1}$ receptor agonist CPA, and provides evidence that LUF5834 is an orthosteric rather than an allosteric ligand. It is interesting to note that the number of receptors labeled by $\left[{ }^{3} \mathrm{H}\right]$ LUF5834 was similar to that labeled by the inverse agonist $\left[{ }^{3} \mathrm{H}\right] \mathrm{DPCPX}$. This is in stark contrast to a previous study using the radiolabelled agonist $\left[{ }^{3} \mathrm{H}\right] \mathrm{CCPA}$. In this study Kourounakis et al. found that $\left[{ }^{3} \mathrm{H}\right] \mathrm{CCPA}$ labeled only $20 \%$ of the binding sites labeled by $\left[{ }^{3} \mathrm{H}\right] \mathrm{DPCPX}[17]$. This suggests then, that while $\left[{ }^{3} \mathrm{H}\right] \mathrm{DPCPX}$ and $\left[{ }^{3} \mathrm{H}\right] \mathrm{LUF} 5834$ can label both $\mathrm{G}$ protein-coupled and uncoupled receptors with high affinity, $\left[{ }^{3} \mathrm{H}\right] \mathrm{CCPA}$ as a full agonist will only label $\mathrm{G}$ protein-coupled receptors. In agreement with the above conclusion $\left[{ }^{3} \mathrm{H}\right] \mathrm{CCPA}$ binding in our hands was completely displaced by GTP whereas increasing concentrations of GTP could only partially displace bound $\left[{ }^{3} \mathrm{H}\right]$ LUF5834. This suggests that $\left[{ }^{3} \mathrm{H}\right]$ LUF5834 can label both $\mathrm{G}$ protein-coupled and -uncoupled receptors, an ability difficult to reconcile with LUF5834 being a full agonist as was shown in an initial study using a whole cell cAMP assay [11]. Similar experiments have been carried out for $\left[{ }^{3} \mathrm{H}\right]$ lisuride, $\left[{ }^{3} \mathrm{H}\right] \mathrm{S} 15535$ and $\left[{ }^{3} \mathrm{H}\right] \mathrm{DOI}$, radiolabelled partial agonists at the $5 \mathrm{HT}_{1 \mathrm{~A}}$, and $5 \mathrm{HT}_{2 \mathrm{~A}}$ receptors, respectively [18-20]. In all cases displacement of these partial agonist radioligands by GTP analogues was 
incomplete. Guanine nucleotide exchange is a very early step in the signal transduction cascade, and hence is less subject to amplification or regulation by other cellular processes [21]. Making use of a $\left[{ }^{35} \mathrm{~S}\right] \mathrm{GTP} \gamma \mathrm{S}$ binding assay we demonstrated that, at the level of nucleotide exchange at the G protein, LUF5834 behaves as a partial agonist with greater potency for the $\mathrm{hA}_{1} \mathrm{R}$ than that of the typical agonist CPA.

The competition binding profile of $\left[{ }^{3} \mathrm{H}\right] \mathrm{LUF5834}$ at the $\mathrm{hA} \mathrm{A}_{1} \mathrm{R}$ was examined using a range of $A_{1} R$ ligands. The competition between $\left[{ }^{3} H\right]$ LUF5834 and unlabeled LUF5834 showed no shift in affinity in response to the addition of $1 \mathrm{mM}$ GTP. The full agonist CPA displayed a biphasic curve with an $\mathrm{IC}_{50 \mathrm{H}}$ of $4.7 \mathrm{nM}$ and an $\mathrm{IC}_{50 \mathrm{~L}}$ of $338 \mathrm{nM}$. With the addition of $1 \mathrm{mM} \mathrm{GTP}$ or pre-treatment of $\mathrm{CHO}-\mathrm{hA}_{1}$ cells with pertussis toxin the high affinity (G protein-coupled) binding population decreased. This suggests that the high affinity site of CPA is dependent on G protein coupling and that in the case of the $h A_{1} R$ and CPA this coupling is to member(s) of the $\mathrm{G}_{\mathrm{i} / \mathrm{o}}$ family of $\mathrm{G}$ proteins. This sensitivity to GTP of the reference agonist CPA was quite distinct from the relative nucleotide insensitivity of LUF5834. However, biphasic isotherms were not limited to full agonist ligands. DPCPX, shown to be a high-affinity inverse agonist in the $\left[{ }^{35} \mathrm{~S}\right]$ GTP $\gamma \mathrm{S}$ experiments, also displayed a biphasic curve with an $\mathrm{IC}_{50 \mathrm{H}}$ of $8.5 \mathrm{nM}$ and an $\mathrm{IC}_{50 \mathrm{~L}}$ of $182 \mathrm{nM}$. Interestingly, in the case of DPCPX the low affinity site was shown to represent the G protein-coupled receptor population and that this $\mathrm{G}$ protein coupling is exclusively mediated by $\mathrm{G}_{\mathrm{i} / \mathrm{o}} \mathrm{G}$ proteins since this low affinity site was lost upon the addition of $1 \mathrm{mM} \mathrm{GTP}$ or by pretreatment of cells with pertussis toxin. Such behaviour by an inverse agonist has not been demonstrated before with other radioligands available 
Consequently, competition studies using $\left[{ }^{3} \mathrm{H}\right]$ LUF5834 in the presence and absence of guanine nucleotides provide useful information as regards to the efficacy of antagonists and inverse agonists at the $\mathrm{hA}_{1} \mathrm{R}$ receptor. Many studies have clearly shown the relationship between the observed change in binding affinity upon addition of guanine nucleotides and agonist efficacy $[23,26]$. Indeed, such a relationship has even been demonstrated at the $A_{1} R$ [25]. In this study we also saw a relationship between the efficacy of the ligand in the $\left[{ }^{35} \mathrm{~S}\right] \mathrm{GTP} \gamma \mathrm{S}$ experiments and the affinity change with the addition of GTP in competition experiments. The changes of affinity for agonists and 
inverse agonists were inversely related. Furthermore, affinity changes observed for partial agonists such as BCPA and ECPA and partial inverse agonists such as N0840 were more modest than those observed for the full agonist CPA and the efficacious inverse agonist DPCPX.

Several studies have used partial agonist or neutral antagonist radioligands to characterise both agonist and inverse agonists at the $5-\mathrm{HT}_{1 \mathrm{~A}}$ receptor $[19,27,28]$. It should be noted that such changes in affinity in the presence of GTP are not observed for inverse agonists at the $h A_{1} R$ when the inverse agonist radioligand $\left[{ }^{3} \mathrm{H}\right] \mathrm{DPCPX}$ is used, despite this ligand labelling populations of both $\mathrm{G}$ protein-coupled and -uncoupled receptor [25]. If the radioligand and 'cold' ligand have a similar efficacy they will be modulated by the addition of nucleotide to a similar extent, and therefore a change in affinity will not be observed. In agreement with this finding, in competition experiments of $\left[{ }^{3} \mathrm{H}\right] \mathrm{LUF5834}$ versus the partial agonist BCPA, no change in affinity was observed in the absence or presence of guanine nucleotide. This can be reconciled with both LUF5834 and BCPA having an identical efficacy in the $\left[{ }^{35} \mathrm{~S}\right] \mathrm{GTP} \gamma \mathrm{S}$ assay. $\left[{ }^{3} \mathrm{H}\right] \mathrm{LUF5834}$ therefore allows the discrimination of high and low affinity sites for both inverse agonists and agonists as demonstrated by displacement studies using CPA and DPCPX.

In summary then we describe the first non-ribose partial agonist radioligand for the $A_{1} R$, LUF5834. This radioligand labels the $\mathrm{hA}_{1}$ receptor with high, sub-nanomolar affinity, higher than any other radioligand available for that receptor. The high affinity of $\left[{ }^{3} \mathrm{H}\right]$ LUF5834, plus its partial agonist nature allows it to bind to both G protein-coupled 
and -uncoupled receptors with similar high affinity. Competition experiments using $\left[{ }^{3} \mathrm{H}\right]$ LUF5834 revealed a population of receptors with a low affinity for inverse agonists such as DPCPX. To our knowledge this study is the first to reveal the affinity of $A_{1} R$ inverse agonists such as DPCPX for the G protein-coupled population of receptors.

There is increasing interest in the potential of adenosine $A_{1}$ receptor partial agonists, e.g. in the treatment of paroxysmal supraventricular tachycardia (PSVT) [4]. Similarly, blockade of $A_{1}$ Rs may be useful in the treatment of neurological disorders such as cognitive decline [29]. $\left[{ }^{3} \mathrm{H}\right]$ LUF 5834 represents a new class of radioligand for the adenosine $A_{1}$ receptor and can be a versatile tool to allow estimations of efficacy for both agonists and antagonists at this increasingly attractive therapeutic target.

\section{Acknowledgements}

This study was performed within the framework of Top Institute Pharma, project number D1-105.

\section{References}

[1] Fredholm BB, IJzerman AP, Jacobson KA, Klotz KN, Linden J. International Union of Pharmacology. XXV. Nomenclature and classification of adenosine receptors. Pharmacol Rev 2001;53:527-52.

[2] Dixon AK, Gubitz AK, Sirinathsinghji DJ, Richardson PJ, Freeman TC. Tissue distribution of adenosine receptor mRNAs in the rat. Br J Pharmacol 1996;118:1461-8.

[3] Jacobson KA, Gao ZG. Adenosine receptors as therapeutic targets. Nat Rev Drug Discov 2006;5:247-64. 
[4] Gao ZG, Jacobson KA. Emerging adenosine receptor agonists. Expert Opin Emerg Drugs 2007;12:479-92.

[5] Peterman C, Sanoski CA. Tecadenoson: a novel, selective A1 adenosine receptor agonist. Cardiol Rev 2005;13:315-21.

[6] Elzein E, Zablocki J. A1 adenosine receptor agonists and their potential therapeutic applications. Expert Opin Investig Drugs 2008;17:1901-10.

[7] Muller CE. Adenosine receptor ligands-recent developments part I. Agonists. Curr Med Chem 2000;7:1269-88.

[8] Soudijn W, van Wijngaarden I, IJzerman AP. Medicinal chemistry of adenosine A1 receptor ligands. Curr Top Med Chem 2003;3:355-67.

[9] Rosentreter U, Kraemer T, Shimada M, Huebsch W, Diedrichs N, Krahn T, et al. Substituted 2-thio-3,5-dicyano-4-phenyl-6-aminopyridines and their use as adenosine receptor-selective ligands. WO patent 2003/03008384, 2003.

[10] Rosentreter U, Kramer T, Shimada M, Hubsch W, Diedrichs N, Krahn T, et al. Substituted 2-thio-3,5-dicyano-4-phenyl-6-aminopyridines and their use as adenosine receptor-selective ligands. US patent 2004/0176417, 2004.

[11] Beukers MW, Chang LC, von Frijtag Drabbe Kunzel JK, Mulder-Krieger T, Spanjersberg RF, Brussee J, et al. New, non-adenosine, high-potency agonists for the human adenosine $\mathrm{A} 2 \mathrm{~B}$ receptor with an improved selectivity profile compared to the reference agonist N-ethylcarboxamidoadenosine. J Med Chem 2004;47:3707-9. 
[12] Chang LC, von Frijtag Drabbe Kunzel JK, Mulder-Krieger T, Spanjersberg RF,

Roerink SF, van den Hout G, et al. A series of ligands displaying a remarkable agonisticantagonistic profile at the adenosine A1 receptor. J Med Chem 2005;48:2045-53.

[13] Heitman LH, Mulder-Krieger T, Spanjersberg RF, von Frijtag Drabbe Kunzel JK, Dalpiaz A, IJzerman AP. Allosteric modulation, thermodynamics and binding to wildtype and mutant (T277A) adenosine A1 receptors of LUF5831, a novel nonadenosinelike agonist. Br J Pharmacol 2006;147:533-41.

[14] Roelen H, Veldman N, Spek AL, von Frijtag Drabbe Kunzel J, Mathot RA, IJzerman AP. N6,C8-distributed adenosine derivatives as partial agonists for adenosine A1 receptors. J Med Chem 1996;39:1463-71.

[15] Klotz KN, Lohse MJ, Schwabe U, Cristalli G, Vittori S, Grifantini M. 2-ChloroN6-[3H]cyclopentyladenosine ([3H]CCPA)--a high affinity agonist radioligand for A1 adenosine receptors. Naunyn Schmiedebergs Arch Pharmacol 1989;340:679-83.

[16] Lohse MJ, Klotz KN, Lindenborn-Fotinos J, Reddington M, Schwabe U, Olsson RA. 8-Cyclopentyl-1,3-dipropylxanthine (DPCPX)--a selective high affinity antagonist radioligand for A1 adenosine receptors. Naunyn Schmiedebergs Arch Pharmacol 1987;336:204-10.

[17] Kourounakis A, Visser C, de Groote M, IJzerman AP. Differential effects of the allosteric enhancer (2-amino-4,5-dimethyl-trienyl)[3-trifluoromethyl) phenyl]methanone (PD81,723) on agonist and antagonist binding and function at the human wild-type and a mutant (T277A) adenosine A1 receptor. Biochem Pharmacol 2001;61:137-44. 
[18] Lopez-Gimenez JF, Villazon M, Brea J, Loza MI, Palacios JM, Mengod G, et al. Multiple conformations of native and recombinant human 5-hydroxytryptamine(2a) receptors are labeled by agonists and discriminated by antagonists. Mol Pharmacol 2001;60:690-9.

[19] Newman-Tancredi A, Verriele L, Chaput C, Millan MJ. Labelling of recombinant human and native rat serotonin $5-\mathrm{HT} 1 \mathrm{~A}$ receptors by a novel, selective radioligand, [3H]S 15535: definition of its binding profile using agonists, antagonists and inverse agonists. Naunyn Schmiedebergs Arch Pharmacol 1998;357:205-17.

[20] Sundaram H, Turner JD, Strange PG. Characterisation of recombinant serotonin 5-HT1A receptors expressed in Chinese hamster ovary cells: the agonist $[3 \mathrm{H}]$ lisuride labels free receptor and receptor coupled to G protein. J Neurochem 1995;65:1909-16.

[21] Milligan G. Principles: extending the utility of [35S]GTP gamma S binding assays. Trends Pharmacol Sci 2003;24:87-90.

[22] Samama P, Cotecchia S, Costa T, Lefkowitz RJ. A mutation-induced activated state of the beta 2-adrenergic receptor. Extending the ternary complex model. J Biol Chem 1993;268:4625-36.

[23] Christopoulos A, Kenakin T. G protein-coupled receptor allosterism and complexing. Pharmacol Rev 2002;54:323-74.

[24] Shryock JC, Ozeck MJ, Belardinelli L. Inverse agonists and neutral antagonists of recombinant human A1 adenosine receptors stably expressed in Chinese hamster ovary cells. Mol Pharmacol 1998;53:886-93. 
[25] de Ligt RA, IJzerman AP. Intrinsic activity at adenosine A1 receptors: partial and inverse agonism. Curr Pharm Des 2002;8:2333-44.

[26] Christopoulos A, El-Fakahany EE. Qualitative and quantitative assessment of relative agonist efficacy. Biochem Pharmacol 1999;58:735-48.

[27] Newman-Tancredi A, Verriele L, Touzard M, Millan MJ. Efficacy of antipsychotic agents at human 5-HT(1A) receptors determined by [3H]WAY100,635 binding affinity ratios: relationship to efficacy for G-protein activation. Eur J Pharmacol 2001;428:177-84.

[28] Newman-Tancredi A, Verriele L, Millan MJ. Differential modulation by GTPgammaS of agonist and inverse agonist binding to h5-HT(1A) receptors revealed by [3H]-WAY100,635. Br J Pharmacol 2001;132:518-24.

[29] Ribeiro JA, Sebastiao AM, de Mendonca A. Adenosine receptors in the nervous system: pathophysiological implications. Prog Neurobiol 2002;68:377-92. 


\section{Table 1}

\section{Estimates of affinity ( $K_{i}$ values) derived from the competition of $\left[{ }^{3} \mathrm{H}\right] \mathrm{DPCPX}$ with} the agonists CPA and LUF5834 at the $h \mathrm{~A}_{1} \mathrm{R}$ expressed in CHO cell membranes. Values represent the means \pm S.E.M. obtained from three to seven experiments conducted in duplicate. Values of $\mathrm{pK}_{\mathrm{h}}$ and $\mathrm{pK}_{1}$ are expressed as $-\log$ values with the corresponding values of $\mathrm{K}_{\mathrm{i}}$ shown in parentheses.

\begin{tabular}{|c|c|c|c|c|c|c|}
\hline & LUF 5834 & $\begin{array}{c}\text { LUF } 5834 \\
\text { + GTP }\end{array}$ & $\begin{array}{c}\text { LUF } 5834 \\
\text { + PTX }\end{array}$ & CPA & $\begin{array}{c}\text { CPA } \\
+ \text { GTP }\end{array}$ & $\begin{array}{r}\text { CPA } \\
+ \text { PTX }\end{array}$ \\
\hline $\begin{array}{l}\mathbf{p K}_{\mathrm{h}} \\
\left(\mathbf{K}_{\mathrm{h}}, \mathbf{n M}\right)\end{array}$ & & & & $\begin{array}{c}8.15 \pm 0.39 \\
(7 \mathrm{nM})\end{array}$ & & \\
\hline $\begin{array}{l}p K_{i} \text { or } p K_{l} \\
\left(K_{i} \text { or } K_{l},\right. \\
n M)\end{array}$ & $\begin{array}{c}8.59 \pm 0.11 \\
(3 \mathrm{nM})\end{array}$ & $\begin{array}{c}8.33 \pm 0.10 \\
(5 \mathrm{nM})\end{array}$ & $\begin{array}{c}8.47 \pm 0.10 \\
(4 \mathrm{nM})\end{array}$ & $\begin{array}{l}6.41 \pm 0.07 \\
(389 \mathrm{nM})\end{array}$ & $\begin{array}{c}6.44 \pm 0.07 \\
(363 \mathrm{nM})\end{array}$ & $\begin{array}{c}6.41 \pm 0.08 \\
(389 \mathrm{nM})\end{array}$ \\
\hline Hill Slope & $0.74 \pm 0.06$ & $0.77 \pm 0.06$ & $0.79 \pm 0.15$ & & & \\
\hline$\% \mathrm{~K}_{\mathrm{h}}$ & & & & $27 \pm 6$ & 0 & 0 \\
\hline
\end{tabular}




\title{
Table 2
}

\author{
Association and dissociation kinetic parameters ( \pm S.E.M.) of $\left[{ }^{3}\right.$ H]LUF5834 binding \\ to $\mathrm{hA}_{1}$ Rs stably expressed in CHO cell membranes. Dissociation was induced with \\ the addition of a large excess of either CPA $(10 \mu \mathrm{M})$ or LUF5834 $(1 \mu \mathrm{M})$. Both \\ association and dissociation curves were best fit using biphasic models. No significant \\ difference was observed between the values of $\mathrm{k}_{\text {off1 }}$ or $\mathrm{k}_{\text {off2 }}$ when either LUF5834 or CPA \\ was used as the displacing ligand (un-paired t test using Prism 5, where statistic \\ significance was taken as $\mathrm{p}<0.05)$
}

\section{Association}

\begin{tabular}{|c|c|c|c|c|}
\hline & $\mathbf{k}_{\text {obs1 }}, \min ^{-1} \cdot M^{-1}$ & Half-life $_{1}$, min & $\mathbf{k}_{\mathrm{obs} 2}, \mathrm{~min}^{-1} \cdot \mathrm{M}^{-1}$ & Half-life $_{2}, \min$ \\
\hline$\left[{ }^{3} \mathbf{H}\right]$ LUF5834 & $0.078 \pm 0.03$ & $14.37 \pm 0.08$ & $1.63 \pm 0.24$ & $0.45 \pm 0.08$ \\
\hline
\end{tabular}

\section{Dissociation}

\begin{tabular}{|c|c|c|c|c|}
\hline Isotopic ligand & $k_{\text {off } 1}, \min ^{-1}$ & Half-life $_{1}$, min & $k_{\text {off2 }}, \min ^{-1}$ & Half-life $_{2}$, min \\
\hline LUF 5834 & $1.07 \pm 0.37$ & $0.93 \pm 0.43$ & $0.05 \pm 0.01$ & $15.83 \pm 4.12$ \\
\hline CPA & $1.96 \pm 1.24$ & $0.98 \pm 0.61$ & $0.06 \pm 0.02$ & $12.77 \pm 4.38$ \\
\hline
\end{tabular}


Table 3

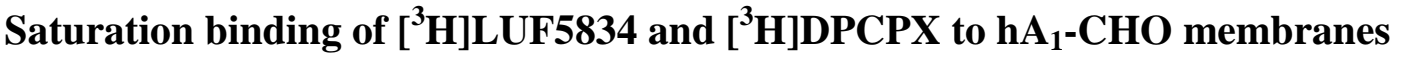

Saturation binding experiments were carried out using at least 12 concentrations of radioligand at $\mathrm{hA}_{1}-\mathrm{CHO}$ membranes in duplicate at least three times. Data for the saturation binding of $\left[{ }^{3} \mathrm{H}\right]$ LUF5834 was best fit using a monophasic binding curve with a variable Hill slope. Three experiments from this series were also well fitted by a biphasic saturation curve. The saturation binding curve for $\left[{ }^{3} \mathrm{H}\right] \mathrm{DPCPX}$ was best fitted by a monophasic curve (F-test using Prism 5, p $<0.05$ was taken as statistically significant).

\begin{tabular}{lccccc}
\hline Radioligand & $\mathbf{K}_{\mathbf{D} 1}, \mathbf{n M}$ & $\mathbf{B}_{\mathbf{m a x} 1}, \mathbf{p m o l} / \mathbf{m g}$ & Hill & $\mathbf{K}_{\mathbf{D} 2}, \mathbf{n M}$ & $\mathbf{B}_{\mathbf{m a x} 2}$ \\
& & & slope & & $\mathbf{p m o l} / \mathbf{m g}$ \\
& & & & & - \\
\hline$\left[{ }^{3} \mathrm{H}\right]$ LUF5834 & $2.03 \pm 0.52$ & $10.70 \pm 0.66$ & $0.78 \pm$ & - & \\
$\mathrm{n}=7$ & & 0.02 & & \\
\hline$\left[{ }^{3} \mathrm{H}\right]$ LUF5834 & $0.16 \pm 0.03$ & $1.70 \pm 0.02$ & - & $1.69 \pm 0.02$ & $9.58 \pm 0.32$ \\
$\mathrm{n}=3$ & & & & & \\
\hline$\left[{ }^{3} \mathrm{H}\right] \mathrm{DPCPX}$ & $2.87 \pm 1.03$ & $12.8 \pm 1.7$ & 1 & - & -
\end{tabular}


Table 4

Estimates of affinity $\left(\mathrm{IC}_{50}\right.$ values) derived from the competition of $\left[{ }^{3} \mathrm{H}\right] \mathrm{LUF5834}$ versus various $A_{1} R$ agonists and antagonists, in the absence and presence of $1 \mathrm{mM}$ GTP, at the $\mathrm{hA}_{1} \mathrm{R}$ expressed in $\mathrm{CHO}$ cell membranes. Values represent the means \pm S.E.M. obtained from three to seven experiments conducted in duplicate. Values of $\mathrm{pK}_{\mathrm{h}}$ and $\mathrm{pK}_{1}$ are expressed as $-\log$ values with the corresponding values of $\mathrm{K}_{\mathrm{i}}$ shown in parentheses. The affinity change was calculated by subtracting the $\mathrm{pIC}_{50 \text { low }}$ value determined in the presence of GTP by the $\mathrm{pIC}_{50 \text { high }}$ value determined in its absence. When no $\mathrm{pIC}_{50 \mathrm{high}}$ could be determined then affinity change was calculated by subtracting the $\mathrm{pIC}_{50 l o w}$ value determined in the presence of GTP by the $\mathrm{pIC}_{50 \text { low }}$ value determined in its absence.

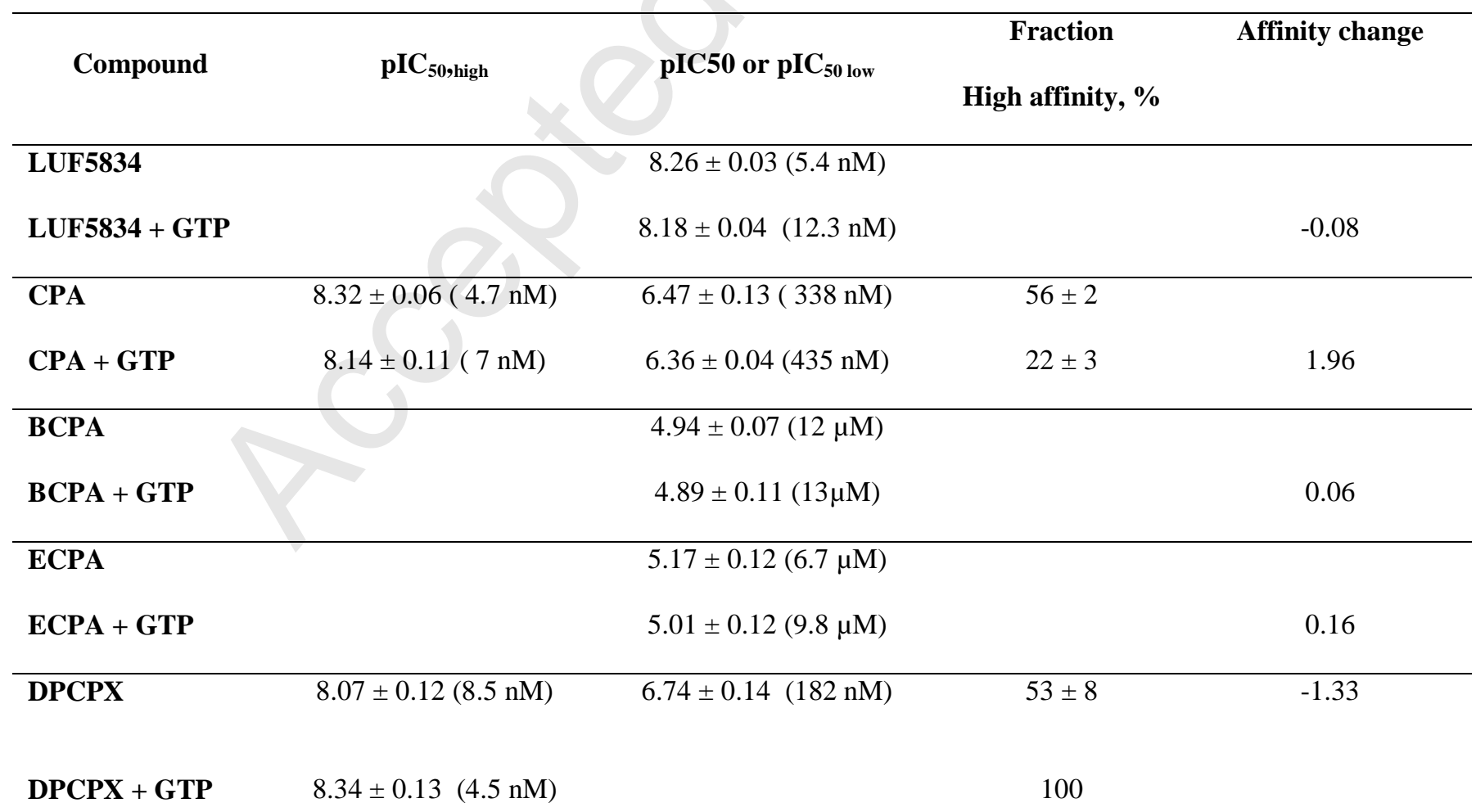




\begin{tabular}{lllcc}
1 & & & \\
2 & & & \\
3 & & & 100 \\
4 & & & -0.92 \\
5 & DPCPX + PTX & $7.96 \pm 0.22(10.9)$ & $44 \pm 11$ & 100 \\
7 & $\mathbf{N 0 8 4 0}$ & $6.34 \pm 0.17(455 \mathrm{nM})$ & $5.10 \pm 0.25(7980 \mathrm{nM})$ & \\
8 & $\mathbf{N 0 8 4 0}+\mathbf{G T P}$ & $6.00 \pm 0.09(995 \mathrm{nM})$ & & \\
9 & & & & \\
\hline 1 & &
\end{tabular}


Table 5: The efficacy and potency of agonists, partial agonists and inverse agonists at the $h A_{1} R$ in a $\left.{ }^{35} S\right]$ GTP $\gamma S$ binding assay. The ability of increasing concentrations of compound to stimulate or inhibit $\left[{ }^{35} \mathrm{~S}\right] \mathrm{GTP} \gamma \mathrm{S}$ binding at $\mathrm{CHO}$ membranes expressing $h A_{1} R$ was determined. $E_{\max }$ was determined as a percentage of the maximal stimulation exerted by the full agonist CPA ((maximal stimulation - basal stimulation)/(maximal CPA stimulation - basal stimulation)). Values of $\mathrm{pEC}_{50}$ are expressed as $-\log$ values with the corresponding values of $\mathrm{EC}_{50}$ shown in parentheses.

\begin{tabular}{|c|c|c|}
\hline & $\begin{array}{l}\mathbf{p E C}_{50} \\
\left(\mathrm{EC}_{50}\right)\end{array}$ & $\mathbf{E}_{\max }$ \\
\hline CPA & $\begin{array}{l}8.31 \pm 0.02 \\
(4.84 \mathrm{nM})\end{array}$ & 100 \\
\hline LUF 5834 & $\begin{array}{l}8.48 \pm 0.02 \\
(3.29 \mathrm{nM})\end{array}$ & $70 \pm 3$ \\
\hline 8BCPA & $\begin{array}{c}5.75 \pm 0.04 \\
(1.78 \mu \mathrm{M})\end{array}$ & $65 \pm 1$ \\
\hline 8ECPA & $\begin{array}{l}6.12 \pm 0.05 \\
(0.79 \mu \mathrm{M})\end{array}$ & $94 \pm 4$ \\
\hline DPCPX & $\begin{array}{c}7.98 \pm 0.14 \\
(11 \mathrm{nM})\end{array}$ & $-18 \pm 3$ \\
\hline N0840 & $\begin{array}{l}4.88 \pm 0.3 \\
(19.7 \mu \mathrm{M})\end{array}$ & $-12 \pm 2$ \\
\hline
\end{tabular}




\title{
Figure 1
}

Displacement of $\left[{ }^{3} \mathrm{H}\right] \mathrm{DPCPX}$ bound to the $\mathrm{hA_{1 }} R$ expressed on CHO cell membranes by increasing concentrations of LUF5834 (A) or CPA (B) with or without the presence of $1 \mathrm{mM}$ GTP or with treatment of the $\mathrm{h} \mathrm{A}_{1}-\mathrm{CHO}$ cells with pertussis toxin (PTX). Points shown are from representative experiments performed in duplicate and repeated on at least three independent occasions. Data was fit using non-linear regression isotherms. The curves for LUF5834 were best fit using a monophasic isotherm with a variable Hill slope both in the presence or absence of GTP or using membranes pretreated with pertussis toxin. Contrastingly data from CPA experiments were best fit by biphasic isotherms in the control condition but monophasic isotherms in the presence of 1 mM GTP or on membranes pre-treated with pertussis toxin (F-test using Prism 5, statistical significance was regarded as $\mathrm{P}<0.05)$.

\section{Figure 2}

\author{
Association (A) to and dissociation (B) of $\left[{ }^{3} \mathrm{H}\right] \mathrm{LUF5834}$ from the $\mathrm{h} \mathrm{A}_{1} \mathrm{R}$ stably \\ expressed on CHO cell membranes. Dissociation of $\left[{ }^{3} \mathrm{H}\right] \mathrm{LUF} 5834$ was achieved by \\ adding CPA $(10 \mu \mathrm{M}, \bullet)$ or LUF5834 $(1 \mu \mathrm{M}, \boldsymbol{\varpi})$. Experiments were performed three \\ times in duplicate. Data shown is from a representative experiment.
}




\section{Figure 3}

Saturation radioligand binding at the $\mathrm{h} \mathrm{A}_{1} \mathrm{R}$ expressed on $\mathrm{CHO}$ cell membranes for $\left[{ }^{3}\right.$ H]LUF5834 (A) or $\left[{ }^{3}\right.$ H]DPCPX (B). Experiments were performed at least three times in duplicate. Representative curves are shown for both experiments. Data from $\left[{ }^{3} \mathrm{H}\right]$ LUF5834 was best fit using non-linear regression to a monophasic curve but with a variable Hill slope (Ai). The deviation of the data from a simple monophasic curve with a Hill slope of unity is well demonstrated by the Scatchard plot (Aii). In contrast data for $\left[{ }^{3} \mathrm{H}\right] \mathrm{DPCPX}$ was best fit using a monophasic curve with a Hill slope of unity $(\mathbf{B i})$, graphically demonstrated by the Scatchard plot (Bii).

\section{Figure 4}

\section{Displacement of $\left[{ }^{3} \mathrm{H}\right] \mathrm{LUF5834}$ bound to the $\mathrm{h} \mathrm{A}_{1} \mathrm{R}$ expressed on $\mathrm{CHO}$ cell} membranes by increasing concentrations of the agonists LUF5834 (A), CPA (B) or the nucleotide GTP $(\mathbf{C})$. Points shown are from representative experiments performed in duplicate and repeated on at least three independent occasions. Data is shown normalised as a percentage of specific radioligand bound (i) or as raw counts (dpm) (ii). The curves for LUF5834 were best fit using biphasic isotherms independent of the presence or absence of GTP. Contrastingly data from CPA experiments were best fit by biphasic isotherms in the control condition but monophasic isotherms in the presence of 1 mM GTP (F-test using Prism 5, statistical significance was regarded as $\mathrm{P}<0.05$ ). The effect of increasing concentrations of GTP on the binding of $\left[{ }^{3} \mathrm{H}\right] \mathrm{LUF} 5834$, the full agonist $\left[{ }^{3} \mathrm{H}\right] \mathrm{CCPA}$ or the inverse agonist $\left[{ }^{3} \mathrm{H}\right] \mathrm{DPCPX}$ was also tested $(\mathbf{C}) .\left[{ }^{3} \mathrm{H}\right] \mathrm{CCPA}$, 
$\left[{ }^{3} \mathrm{H}\right]$ LUF5834 and $\left[{ }^{3} \mathrm{H}\right]$ DPCPX were used at concentrations of $1.6 \mathrm{nM}, 2.6 \mathrm{nM}$ and $2 \mathrm{nM}$ respectively, values approximately equal to the respective $K_{d}$ values at this receptor.

\section{Figure 5}

\section{Displacement of $\left[{ }^{3} \mathrm{H}\right] \mathrm{LUF5834}$ bound to the $\mathrm{hA}_{1} \mathrm{R}$ expressed on $\mathrm{CHO}$ cell} membranes by increasing concentrations of the partial agonists 8-butylamino-CPA (8BCPA, A) or 8-ethylamino-CPA $(8 \mathrm{ECPA}, \mathrm{B})$ in the absence or presence of $1 \mathrm{mM}$ GTP. Points shown are from representative experiments performed in triplicate and repeated on at least three independent occasions. Data was fit using non-linear regression isotherms. The curves for both DPCPX and N0840 experiments were best fit by monophasic isotherms both in the absence and the presence of $1 \mathrm{mM} \mathrm{GTP}$ (F-test using Prism 5, statistical significance was regarded as $\mathrm{P}<0.05$ ).

\section{Figure 6}

\section{Displacement of $\left[{ }^{3} \mathrm{H}\right] \mathrm{LUF5834}$ bound to the $\mathrm{hA} \mathrm{A}_{1} \mathrm{R}$ expressed on $\mathrm{CHO}$ cell membranes by increasing concentrations of the antagonists DPCPX (A) and N0840} (B). Points shown are from representative experiments performed in triplicate and repeated on at least three independent occasions. Data was fit using non-linear regression isotherms. The curves for both DPCPX and N0840 experiments were best fit by biphasic isotherms in the control condition but monophasic isotherms in the presence of $1 \mathrm{mM}$ GTP (F-test using Prism 5, statistical significance was regarded as $\mathrm{P}<0.05$ ). 


\section{Figure 7}

\section{${ }^{35}$ S $]$ GTP $y$ S binding experiments reveal LUF5834 to be a partial agonist at the}

$\mathbf{h A}_{\mathbf{1}} \mathbf{R}$. The ability of increasing concentrations of the full agonist CPA, the partial agonists BCPA and ECPA, the inverse agonists DPCPX or N0840 and LUF5834 to stimulate or inhibit $\mathrm{hA}_{1} \mathrm{R}$-mediated nucleotide exchange was tested. A $\left[{ }^{35} \mathrm{~S}\right] \mathrm{GTP} \gamma \mathrm{S}$ assay was performed using $\mathrm{CHO}-\mathrm{hA}_{1}$ membranes. Experiments were performed in duplicate to $\mathrm{N}=3$. Data from a representative experiment are shown. 
1 A)
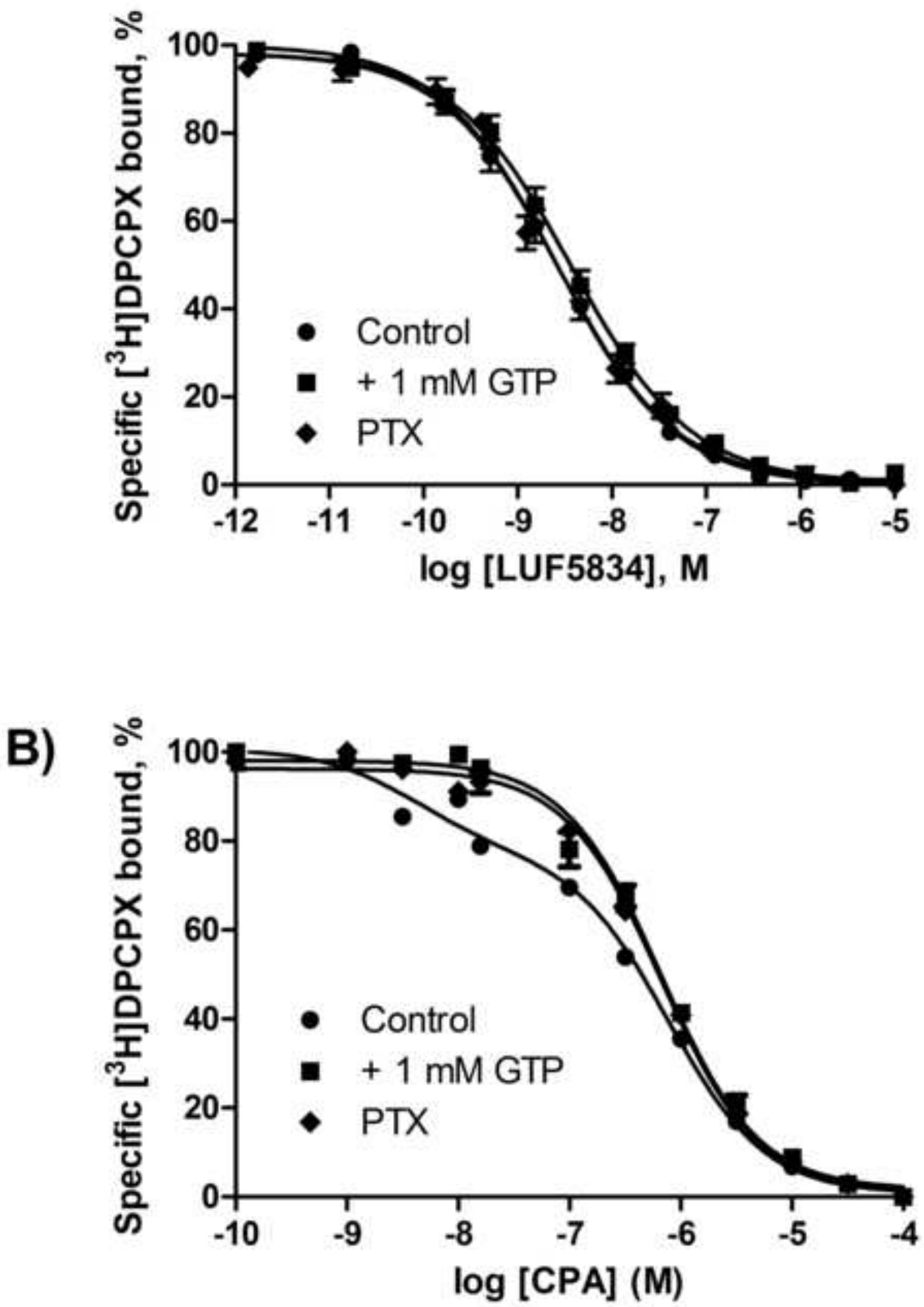
2A)

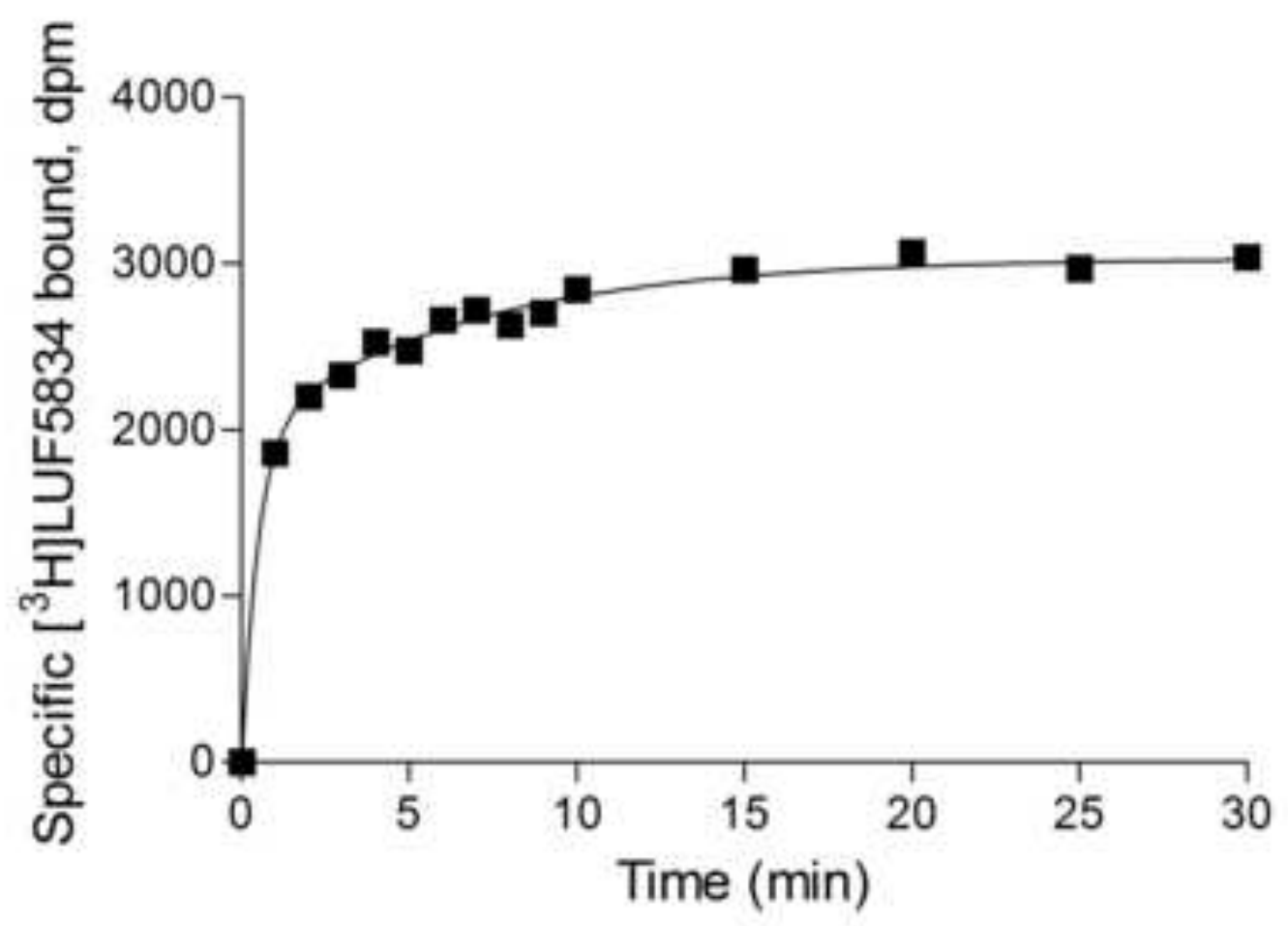

B)

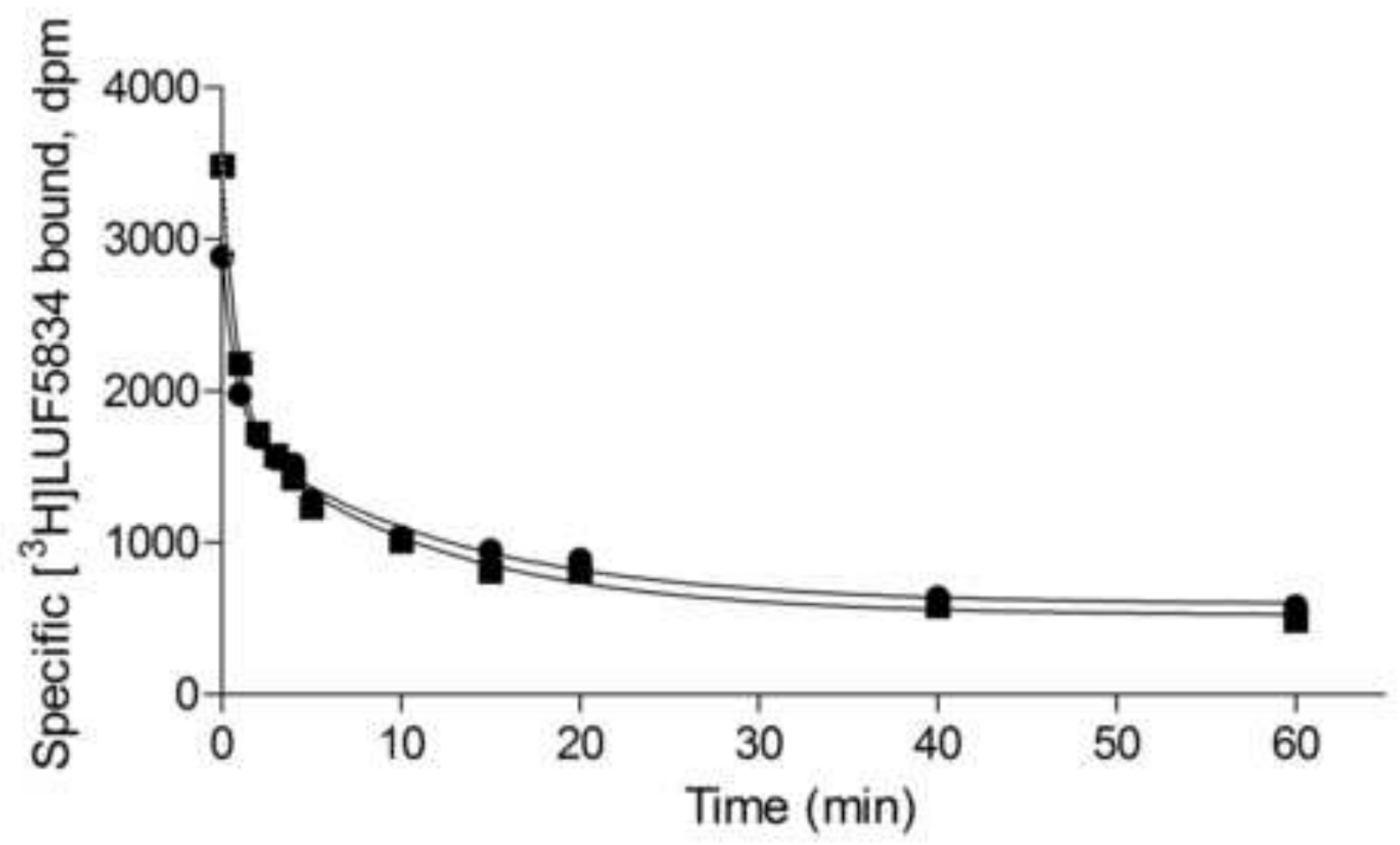


i

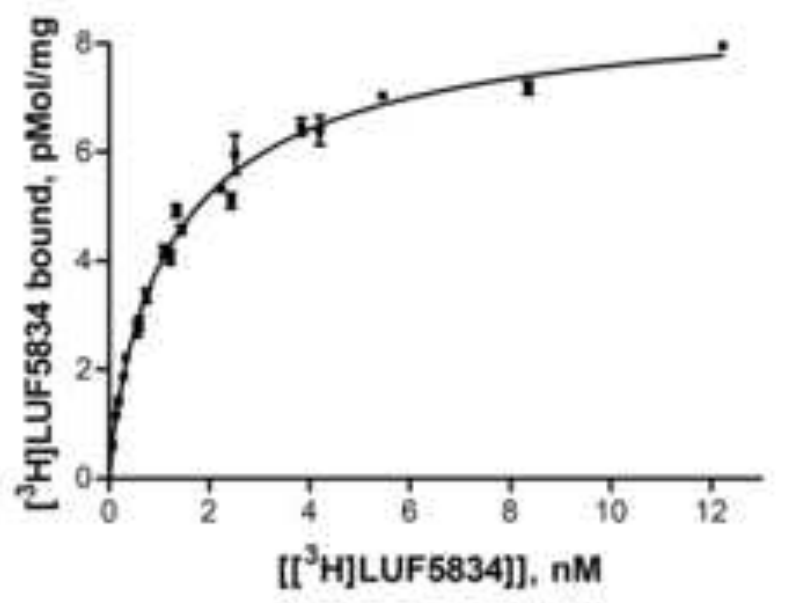

B)

i

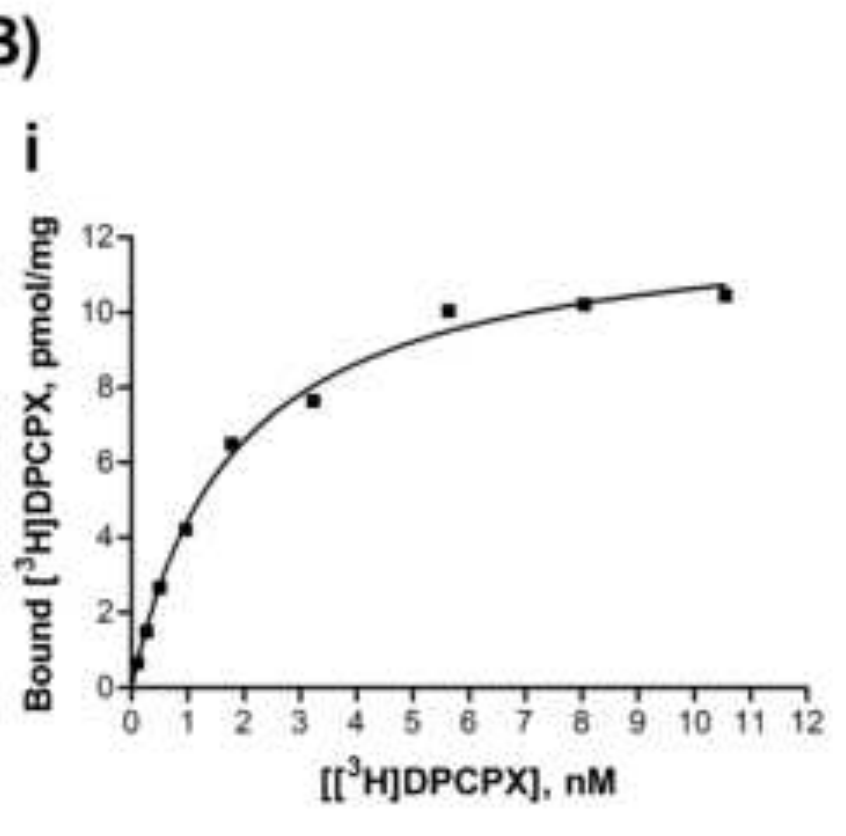

ii

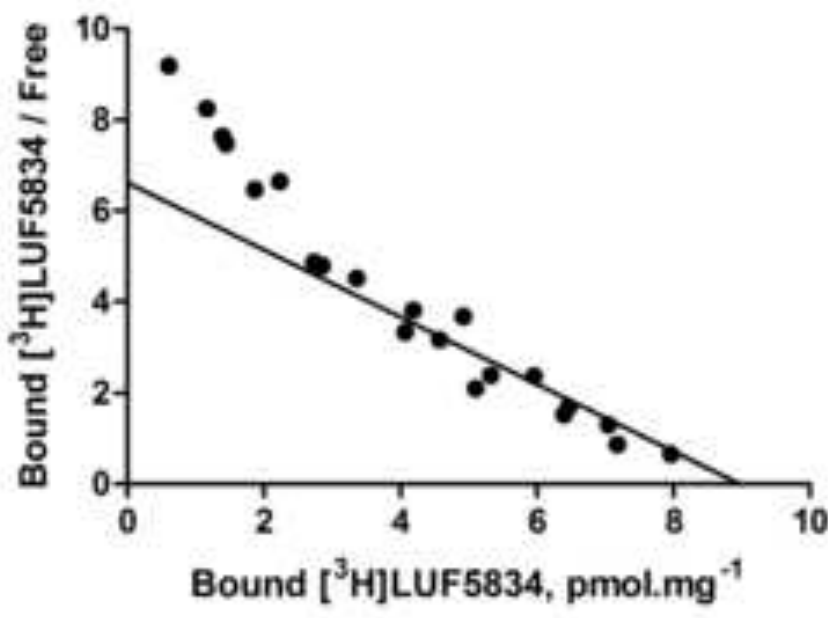

ii

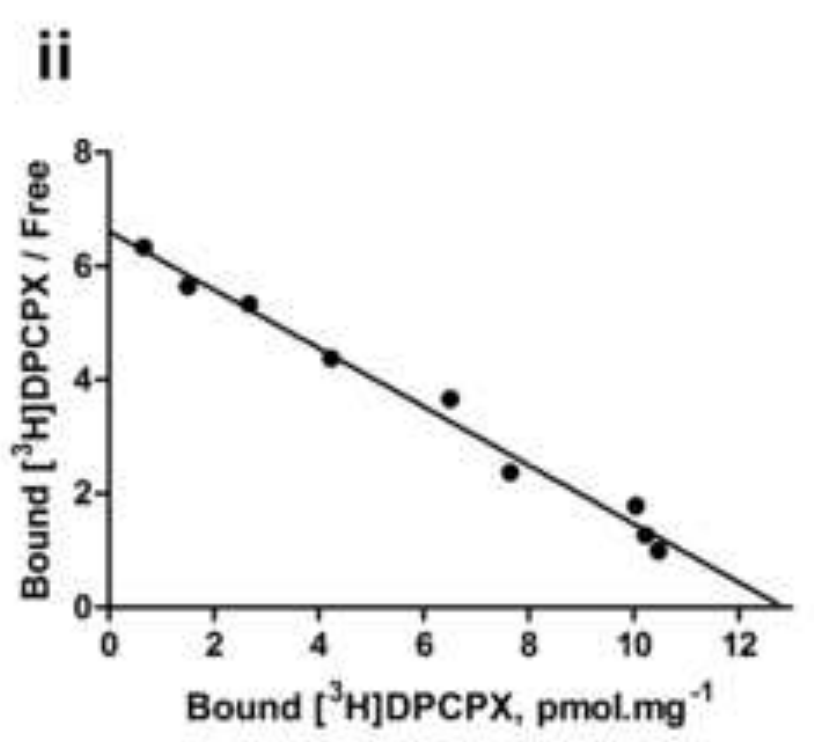

rage 42 or 4 / 


\section{A) i}

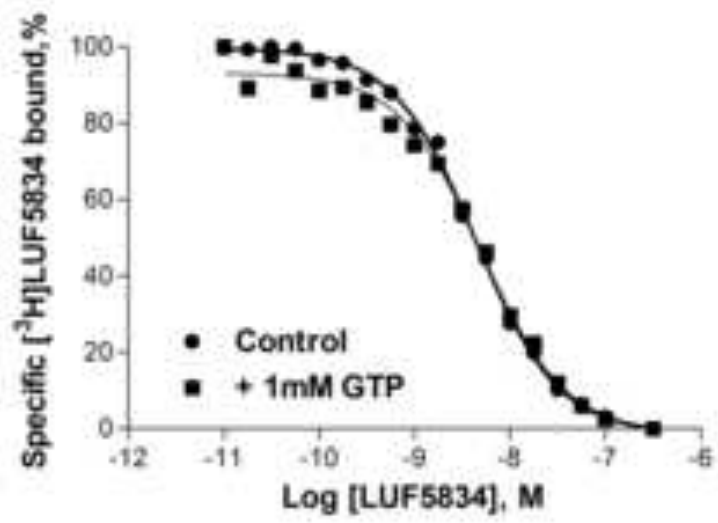

\section{B) i}

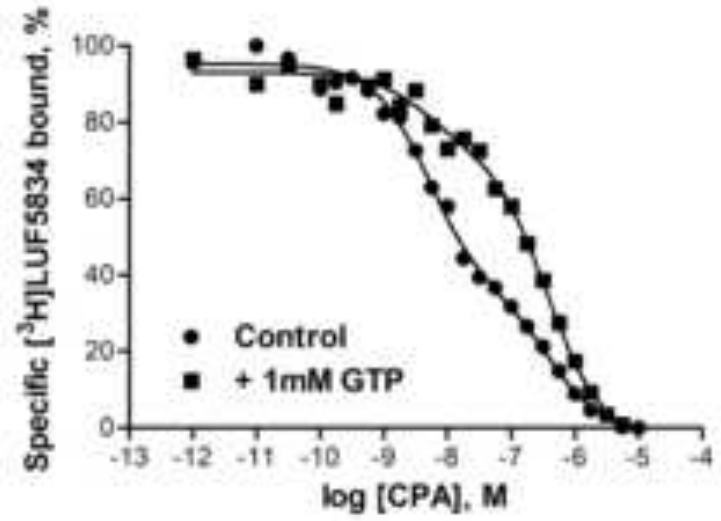

C)

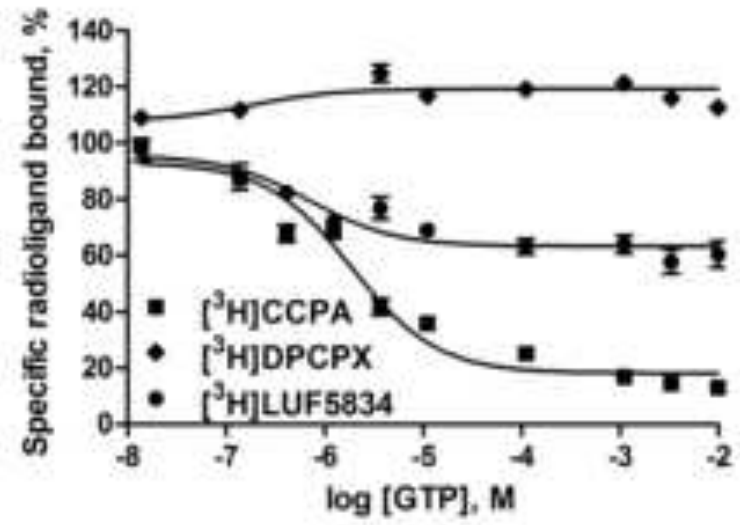

ii
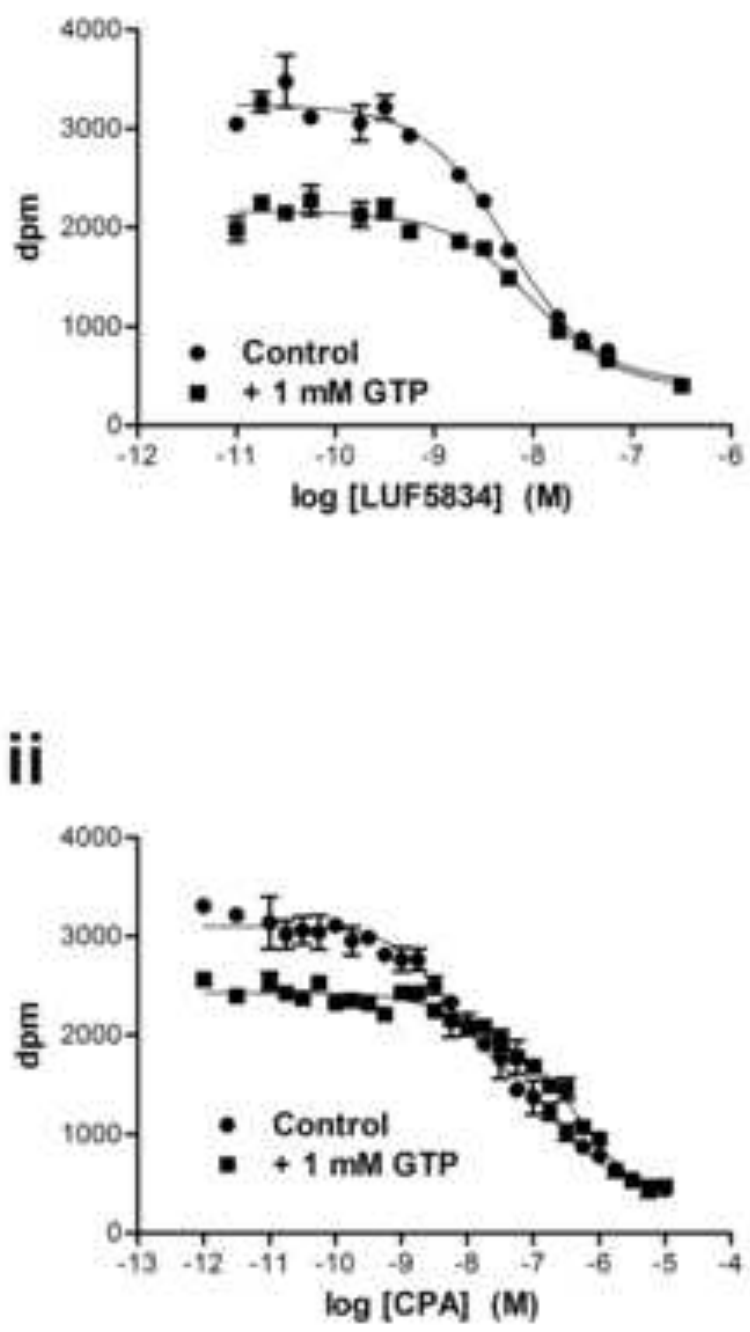


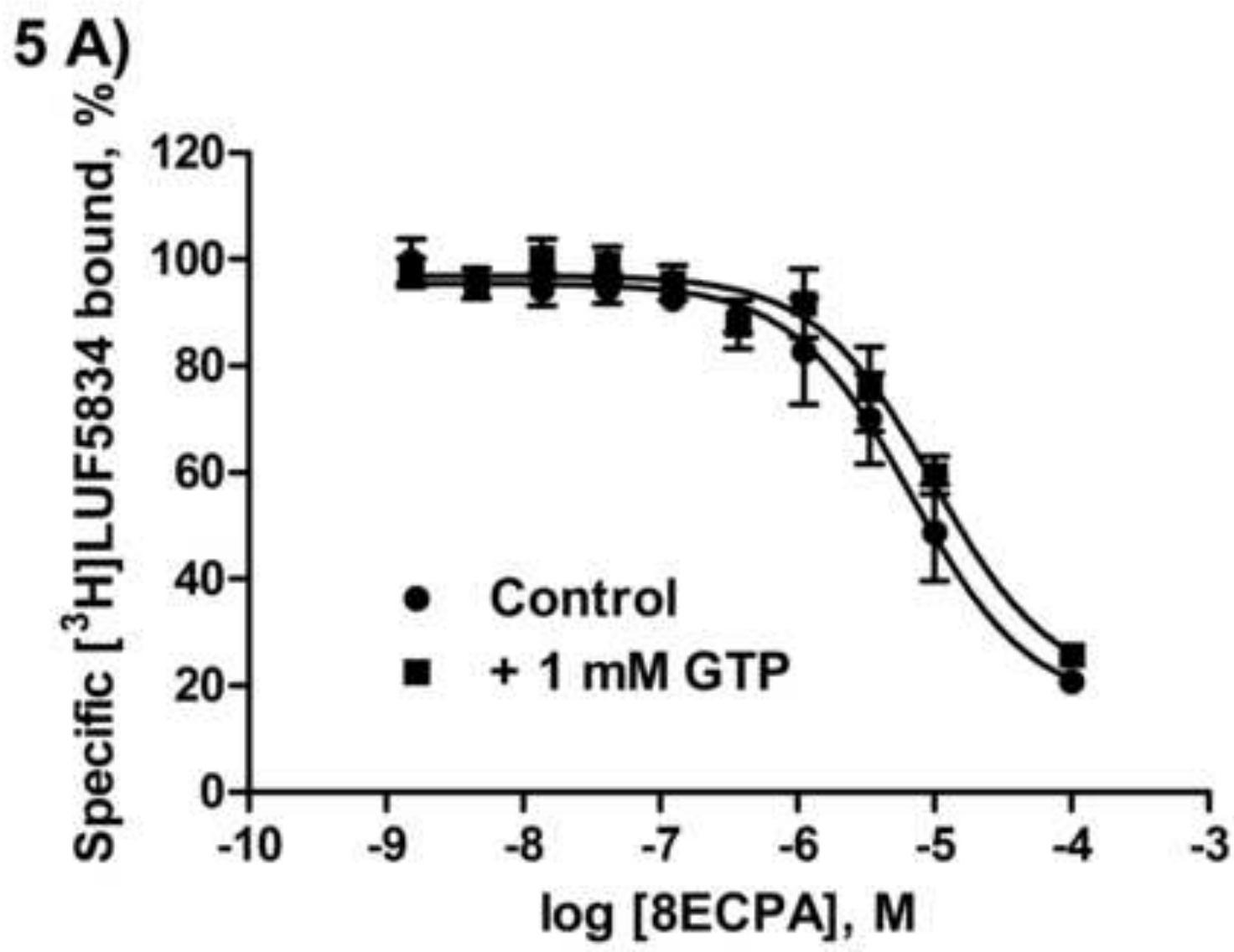

B)

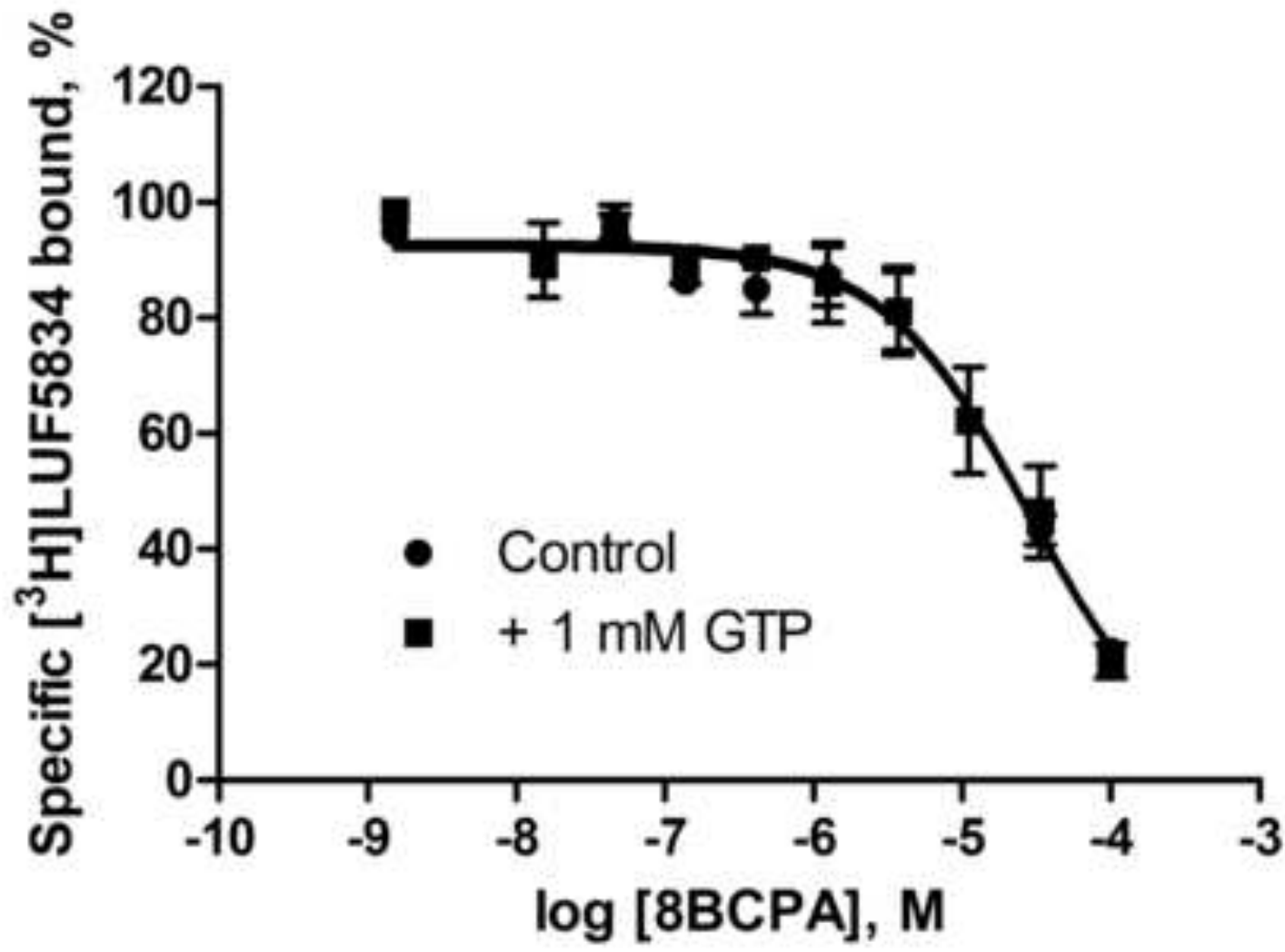


6 A)

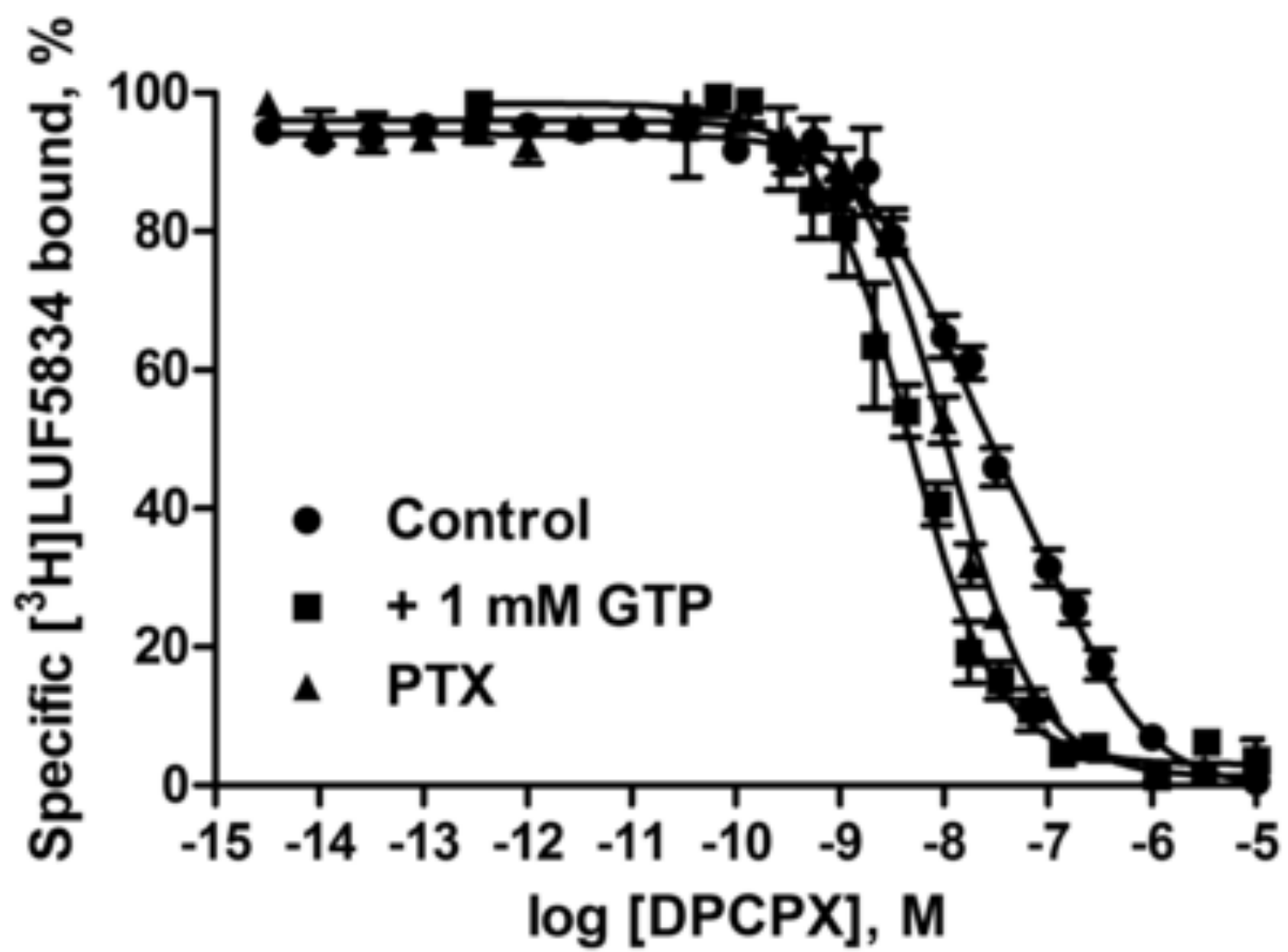

B)

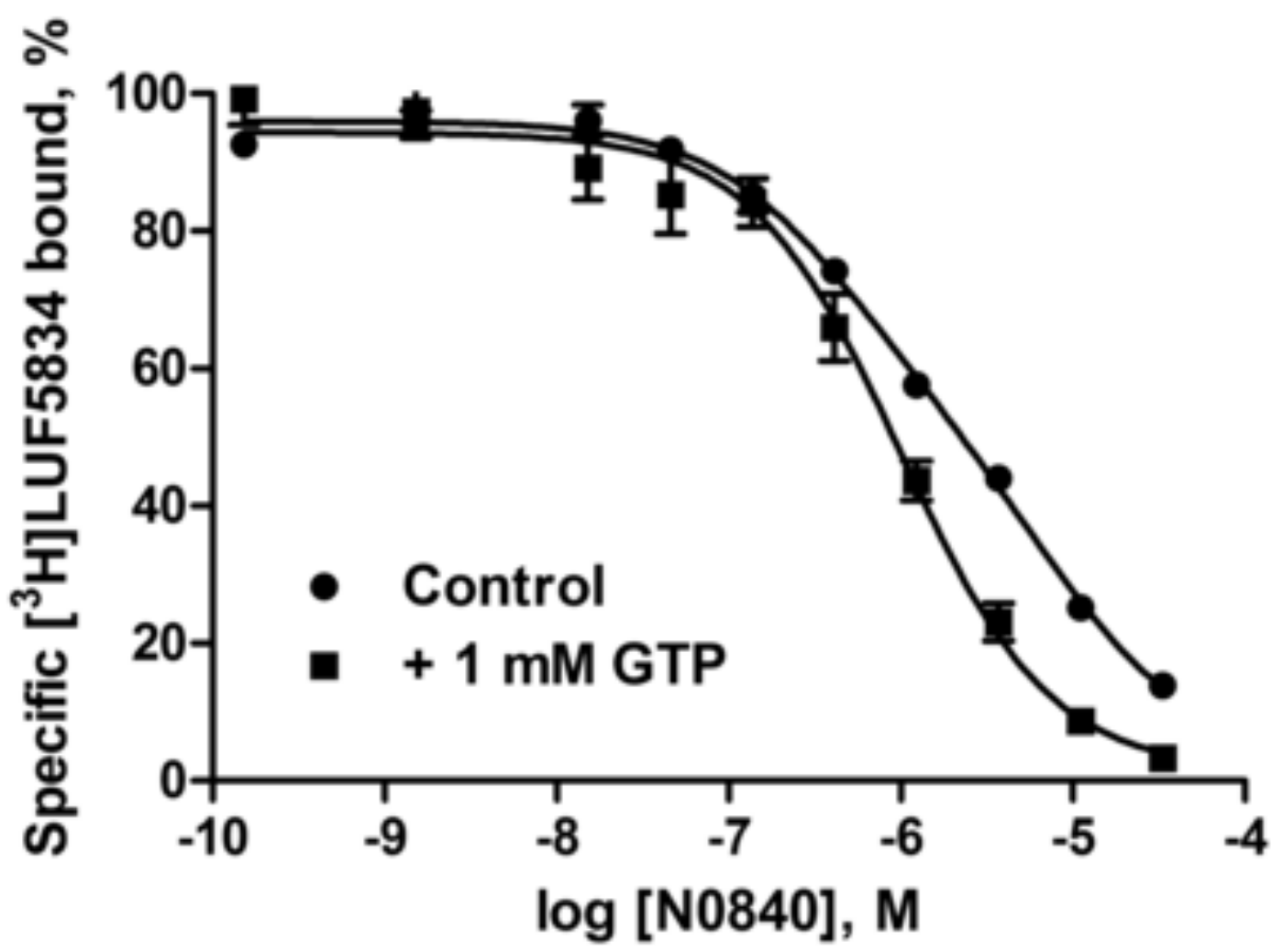


7)

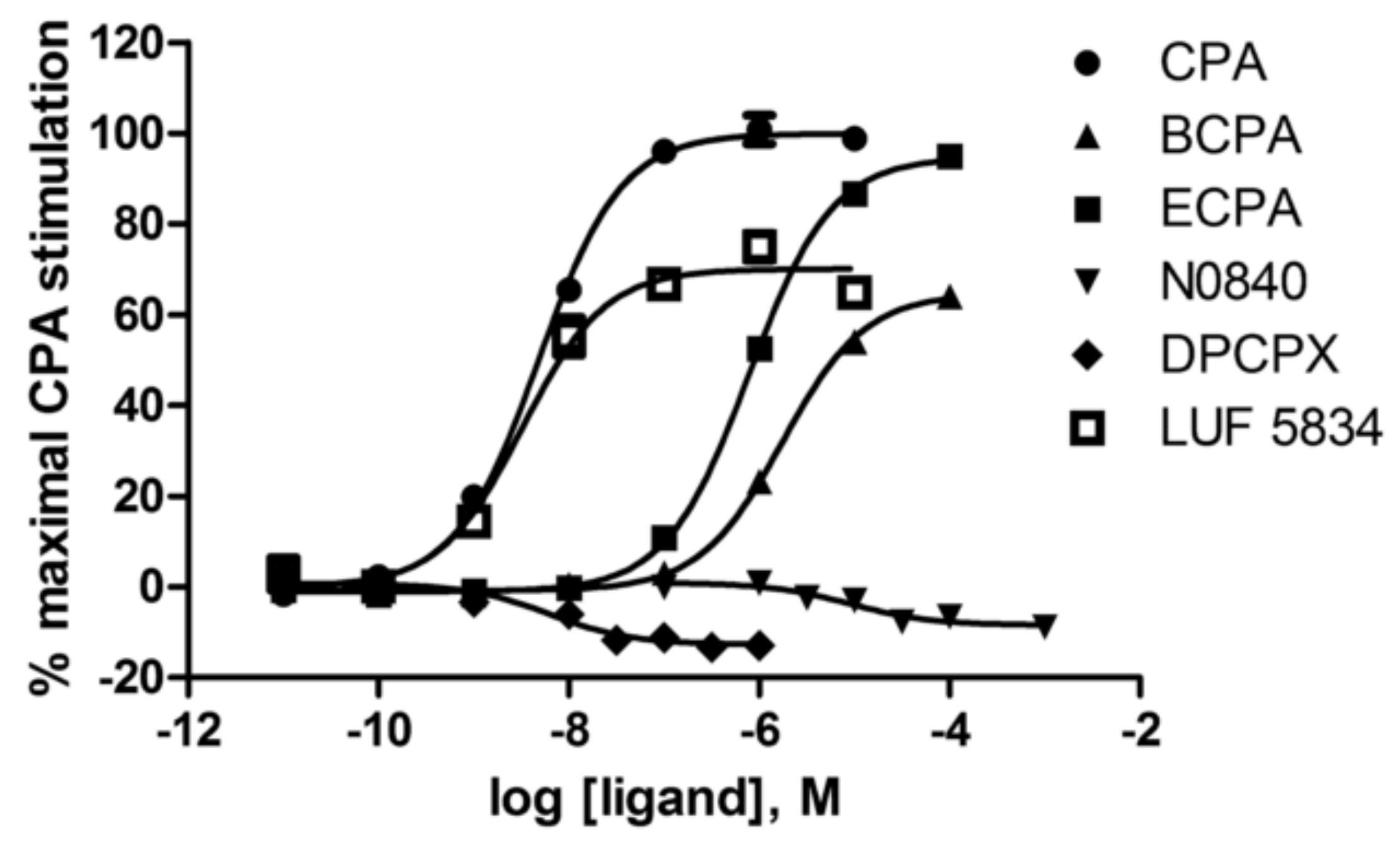




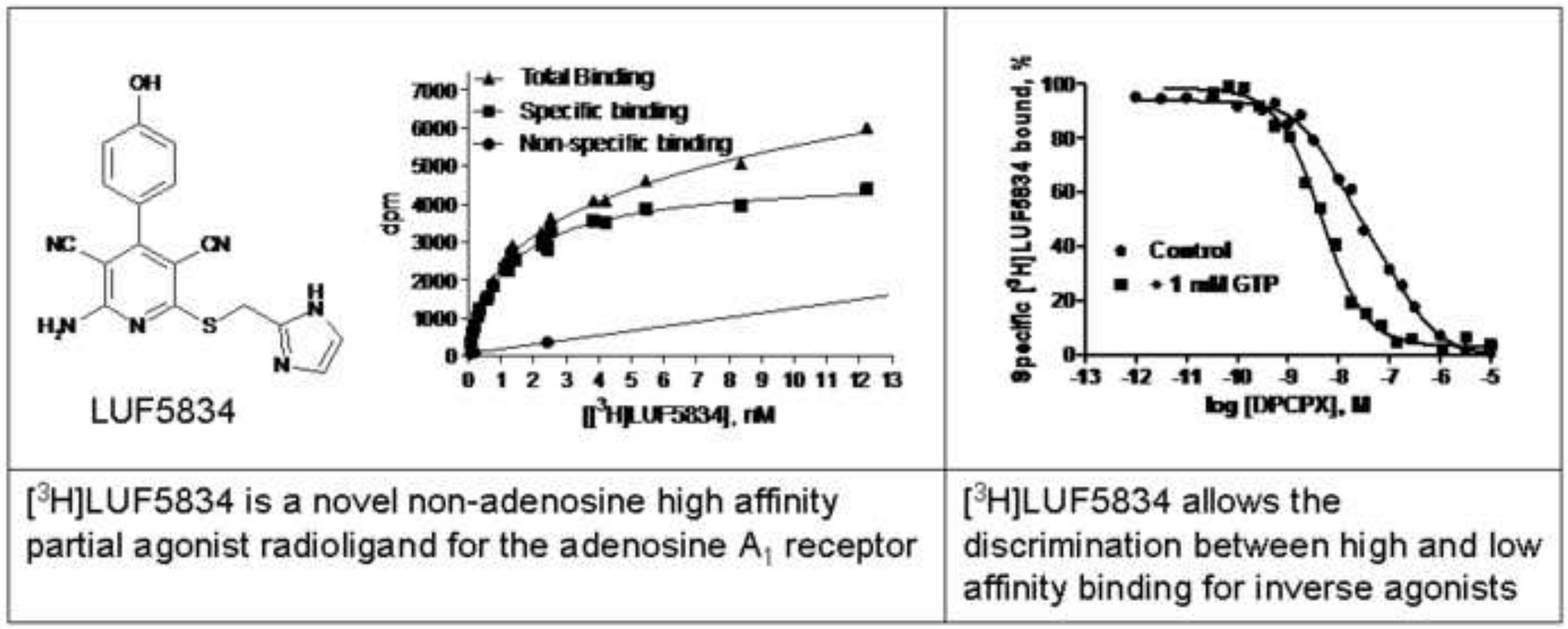

